Discussion

Papers

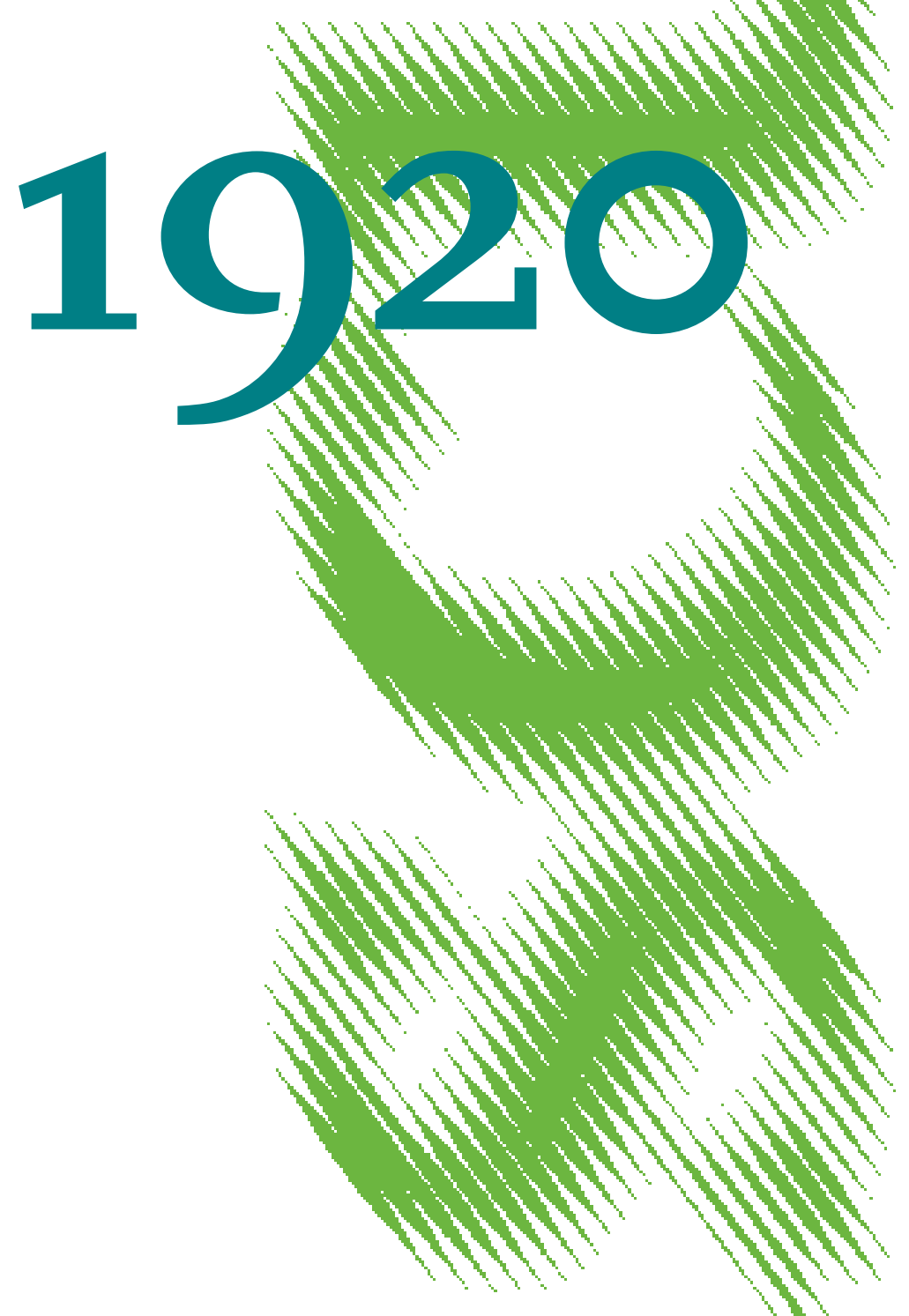

Subgroup Analysis of Investment Constraints: Evidence from Ugandan Microenterprises 
Opinions expressed in this paper are those of the author(s) and do not necessarily reflect views of the institute.

IMPRESSUM

(C) DIW Berlin, 2020

DIW Berlin

German Institute for Economic Research

Mohrenstr. 58

10117 Berlin

Tel. +49 (30) $89789-0$

Fax +49 (30) $89789-200$

http://www.diw.de

ISSN electronic edition 1619-4535

Papers can be downloaded free of charge from the DIW Berlin website:

http://www.diw.de/discussionpapers

Discussion Papers of DIW Berlin are indexed in RePEc and SSRN:

http://ideas.repec.org/s/diw/diwwpp.html

http://www.ssrn.com/link/DIW-Berlin-German-Inst-Econ-Res.html 


\title{
Subgroup Analysis of Investment Constraints: Evidence from Ugandan Microenterprises
}

\author{
Helke Seitz* \\ Leibniz University Hannover \\ German Institute for Economic Research (DIW Berlin)
}

November 2020

\begin{abstract}
Most microenterprises barely grow beyond subsistence level, as profitable investments are not realized due to barriers like credit, savings, and managerial constraints. Using panel data, this study identifies subgroups that would benefit by an intervention aiming to alleviate constraints. Two obstacles are associated with lower investments: saving with others and no record keeping. Analyzing the effects for subgroups shows that for lower and medium educated, both obstacles are associated with lower investments. The analysis does not allow for drawing causal conclusions, results underpin that interventions aiming to reduce savings or managerial constraints could be effective when targeting the correct subgroups.
\end{abstract}

Keywords: Entrepreneurship, Investment, Credit Constraints, Savings Constraints, Managerial Constraints

JEL Codes: D22, D25, O12, O16

*e-mail: hseitz@diw.de. Corresponding address: German Institute for Economic Research (DIW Berlin), Department of International Economics, Mohrenstraße 58, 10117 Berlin, Germany, Tel: +49 30 89789 519, Fax +49 3089789 102. This work was supported by the German Research Foundation (DFG). The financial support received is gratefully acknowledged. I thank Antonia Grohmann, Tim Kaiser, Tabea Lakemann, Katharina Lehmann-Uschner, Lukas Menkhoff, Susan Steiner, and participants of conferences in Göttingen, Hannover, and Helsinki for helpful and valuable comments. In particular I thank Jana Hamdan and Melanie Koch for her intense and valuable support 


\section{Introduction}

Many developing countries face the enormous challenge of a rapidly growing working age population. This is due to major demographic shifts caused by increasing infant survival rates and life expectancies. Micro and small enterprises account for the largest fraction of employment in developing countries. However, as firms typically face various constraints, they tend to remain small (Woodruff, 2018). One key policy question is if interventions aiming to alleviate such constraints can foster growth and job creation by micro and small enterprises, thus addressing the employment challenge.

The most prominent constraints correlated with low firm growth discussed in the literature are credit, savings, and managerial. Being credit constrained means having insufficient access to external capital, like formal and informal loans (McKenzie and Woodruff, 2008; De Mel and McKenzie, 2011; Banerjee and Duflo, 2014). In addition, entrepreneurs can be savings constrained as they often undersave; that is, the inability to accumulate sufficient amounts of own savings Banerjee and Duflo, 2007; Dupas and Robinson, 2013a). Lastly, managerial constraints represent the lack of business skills (managerial capital) that are seen as an inherent determinant of firm performance (Bloom et al., 2010, Bruhn et al., 2010, Bruhn and Zia, 2013. McKenzie and Woodruff, 2013).

The existing literature documents several interventions that aim to relax the aforementioned constraints. However, among the target groups of the intervention, some subgroups benefit more than others. Estimated treatment effects are found to vary, for example with respect to gender in studies aiming to relax managerial constraints (Gine and Mansuri, 2014), savings constraints (Dupas and Robinson, 2013a), and credit constraints (De Mel et al. 2008). 1. Other studies find that effects differ by educational level, as for example in interventions providing business train-

\footnotetext{
${ }^{1}$ Gine and Mansuri (2014), implement a business training and find positive effects for men on business knowledge, business practices, and household expenditures. Dupas and Robinson (2013a) provide access to bank accounts and find that only female market vendors save and invest more, unlike male bicycle drivers. De Mel et al. (2008), providing grants, find significant returns for male-owned business.
} 
ings (Bjorvatn and Tungodden, 2010, Drexler et al., 2014, Calderone et al., 2018). 2 $^{2}$ Generally, the observation of heterogeneous treatment effects suggests that often the chosen target group of interventions does not match the group of individuals that would benefit most. Therefore, Drexler et al. (2014) and Nichter and Goldmark (2009) note that it is essential to correctly match client characteristics with the type of training that will be useful for them.

This paper addresses this potential mismatch by identifying the subgroup(s) that would benefit most from an intervention aiming to alleviate obstacles related to credit, savings, and managerial constraints. To address this research question, the paper proceeds in three steps. Firstly, based on 16 obstacles related to credit, savings, and managerial constraints, it analyzes which obstacles are associated with lower firm investments. Secondly, the determinants of each constraint are discussed. Thirdly, the core research question is addressed by investigating for which subgroups relevant constraints affect firm investments most severely and, hence, would benefit from an intervention aiming to relax the constraints. The focus is on subgroups with respect to gender and educational level.

This paper contributes to the literature on the implementation of interventions. Firstly, it addresses the issue that different firms are confronted with various constraints and, hence, that a "one-size-fits all training program" Fischer and Karlan, 2015 , p.296) is not suitable for all firms. Therefore, this paper tackles the question of "which constraint(s) should actually be addressed in an intervention." Secondly, interventions typically focus on relaxing constraints of individuals in heterogeneous samples, thereby assuming that most individuals will benefit. However, the frequently reported presence of heterogeneous treatment effects requires diagnosing the characteristics of firms that are subject to specific constraints more carefully (Fischer and Karlan, 2015). Therefore this paper contributes to identifying individ-

\footnotetext{
${ }_{2}^{\text {Bjorvatn and Tungodden }(2010)}$ find that the effect of business training on entrepreneurial performance is higher for the lower educated; similarly, Drexler et al. (2014) show that participants starting from lower levels of skills benefit from a less complex training (rule-of-thumb training) than from standard accounting training. Calderone et al. (2018) evaluate a financial education program and find that financial attitudes change more among less educated individuals.
} 
uals who would benefit the most from well targeted interventions.

One challenge is the measurement of each constraint. As these are neither directly observable nor measurable, the study relies on "proxy variables" or "obstacles" related to each constraint. These are selected based on the literature. The analyses use a five-year panel dataset of micro and small enterprises (MSEs) in Kampala, Uganda. Generally, studying the development of MSEs is relevant for many developing countries as most of the labor force primarily works as own-account or as unpaid family workers. In the Ugandan case, this share amounts to 80 percent (The Republic of Uganda, 2014). Further, the aforementioned employment challenge is especially pressing in Uganda, a country with high fertility rates (5.6 births per woman in 2016), decreasing infant mortality rates, and increasing life expectancy.$^{3}$ While around 700,000 people entered the labor market in 2013 approximately 1,400,000 will enter in 2040 (The Republic of Uganda, 2014).

In contrast to existing studies that analyze the importance of different constraints 4 this paper focuses on a narrow and pre-defined set of obstacles based on the literature of micro and small enterprise development: credit, savings, and managerial constraints. Undoubtedly, these three constraints are not the only obstacles for micro and small businesses. However, these constraints are among the most important and frequent ones studied in the literature, as motivated in the following section.

This study finds that, in the overall estimation sample, out of sixteen obstacles related to credit, savings, and managerial constraints, only two are found to be relevant: whether people save with others (and, hence, need to protect their savings) and whether people keep good records of their business. These constraints are associated with 31 to 36 percent lower firm investments, after controlling for a large set

\footnotetext{
${ }^{3}$ Life expectancy at birth increased from 53.7 to 59.6 between 2006 and 2016, while at the same time the infant mortality rate (the number of infants dying before reaching one year of age, per 1,000 live births) decreased from 64 to 37 (all data from World Development Indicators, The World Bank).

${ }^{4}$ Among these constraints are, for example, financing constraints (Dinh and Clarke, 2012, Ayyagari et al. 2017), environmental factors, such as crime and policy instability (Ayyagari et al., 2008), and country-specific factors, such as road infrastructure or cell phone communication, as identified in a casestudy of Tanzanian enterprises (Kinda, 2008).
} 
of business owner and firm characteristics. An analysis on the determinants reveals that lower education, ability, experience, and operating without employees are characteristics that strengthen the presence of both constraints. Investigating whether business investments differ by heterogeneous groups shows that education is crucial: if the lower and medium educated do not keep records for their business, significantly lower investments result when compared to the higher educated. The same pattern is found in case of unprotected savings. No difference is found between men and women. In general, the results indicate that ex-ante pre-selecting subgroups can sharpen the focus on an optimal target group, thus increasing the effectiveness of the interventions.

The remainder of this paper is as follows. Section 2 provides a literature overview of the aforementioned constraints. The data, sample, measurement of constraints, and explanatory variables are described in Section 3 . Section 4 provides an empirical answer to the research questions, while Section 5 concludes.

\section{Literature Review}

This analysis builds on the literature that studies obstacles related to credit, savings, and managerial constraints. The literature provides ample empirical evidence for the presence of these constraints among micro and small enterprises in developing countries. In addition, several attempts have been made in the form of implemented interventions to overcome these constraints.

Credit Constraints. Being credit constrained describes the insufficient access to capital that stems from outside the business which can be borrowed from formal (e.g. banks, microfinance institutions, savings and credit cooperatives) or informal (e.g. friends, relatives, business partners, moneylenders) sources or institutions. In general, there is broad evidence that micro and small enterprises are severely credit constrained. Simplest evidence is obtained from survey responses by firm owners or managers. A representative sample of Ivorian manufacturing firms for example shows 
that the severity of financial constraints (e.g. lack of credit) depends on firm size and is a more pressing obstacle among micro and small enterprises compared to larger firms (Sleuwaegen and Goedhuys, 2002). Further evidence stems from studies that analyze the use of provided capital or that compare estimated returns to capital with market interest rates. Banerjee and Duflo (2014), for example, evaluate the provision of microcredits to entrepreneurs. They make use of a policy reform that changes the eligibility for credits. Their results show that firms use access to credit to finance more production, which hints at credit constraints. In contrast, unconstrained firms would not expand production but rather substitute for other borrowing. Other studies apply a similar experimental design and provide microentrepreneurs with cash and in-kind grants (De Mel et al., 2008; McKenzie and Woodruff, 2008; Fafchamps et al. 2014). The estimations of monthly returns to capital are large, ranging between 4.6 percent (De Mel et al., 2008), 15 percent (Fafchamps et al., 2014) and 20 percent (McKenzie and Woodruff, 2008). Returns to capital exceeding market interest rates hint at severe credit constraints, as the optimal level of capital would result in returns to capital that equal market interest rates Banerjee and Duflo, 2005). Lack of access to external capital only is a constraining growth factor in case firm probability is high.

While there is sufficient evidence that business owners are credit constrained, the underlying reasons can be explained by supply and demand side factors. Supply side reasons span around the availability of financial institutions. Comparing access to banks between industrial and developing countries shows a large gap. While 81 percent of adults are estimated to be banked in industrial countries, this share amounts to only 28 percent in developing countries (Kendall et al., 2010) $5^{5}$ Hence, one supply-side reason for being credit constrained is the insufficient physical access to banks, which results in long distances to the nearest bank branch. Expanding access to banks for the case of India shows that not only were households able to easier access a bank credit and saving opportunities, but also that overall rural

\footnotetext{
${ }^{5}$ These numbers reflect a lower level of financial inclusion in developing countries. While the numbers are based on individual data, the general problem also translates to own-account worker and microenterprises.
} 
poverty decreased in the affected areas (Burgess and Pande, 2005, Burgess et al. 2005) 6

In addition, demand-side credit constraints relate for example to a lack of financial literacy. Reasons are that not only could people lack the financial literacy to understand credit, but even if they do understand it, they might not know how to actually apply for it. De Mel and McKenzie (2011) conduct an intervention providing information about the availability of loans (at market interest rates) and the procedure on how to apply for one. While the intervention doubled the proportion of firms receiving credits, only 10 percent of invited business owners received a loan. The study also shows that while the lack of information on loans could be reduced, other practical limiting factors still play a role; such as the inability to find guarantors or bureaucratic procedures.

Savings Constraints. Another way of being financially constrained is the inability to accumulate sufficient amounts of savings, from business profits or other labor income, which can then be re-invested into the business. One obvious reason of why individuals undersave in developing countries might be that people are too poor to save. However, Banerjee and Duflo (2007) argue that people could (simply) save more without cutting spending on subsistence consumption by spending less on temptation goods. But despite their argument, simply saving more is not easy to implement in practice as people might lack a safe place to store their savings, e.g. bank account (Banerjee and Duflo, 2007). In addition to securing money, bank accounts might also prevent loss of savings in cases of lower bargaining power within the household and also makes it easier to withstand temptation as the money is not immediately accessible.

Interventions experimentally providing access to bank accounts show high takeup rates, increased savings and business investments (Dupas and Robinson, 2013a, Prina, 2015) .7 A similar treatment that provides a lock box to secure savings finds

\footnotetext{
${ }^{6}$ While this literature focuses on beneficial effects of a bank expansion on households, it is plausible to assume that businesses also profit from improved access to savings and borrowing opportunities.

${ }^{7}$ (Dupas and Robinson, 2013a) find heterogeneous treatment effects by gender.
} 
that usage is high, to be precise, 12 months after receiving lock boxes, between 66 and 71 percent of participants have positive amounts in their lock box (Dupas and Robinson, 2013b). In support of these promising effects on savings outcomes, a meta study evaluating interventions with saving promotion components finds positive effects on savings accumulation (Steinert et al. 2018 ). Despite secure places to store savings, there are of course other factors that lead to undersaving, such as transaction costs, lack of trust, information and knowledge gaps, social constraints, and behavioral biases Karlan et al. (2014). 8

Managerial Constraints. A third constraint receiving increased attention is the lack of managerial capital (Bloom et al. 2010, Bruhn et al. 2010). Managerial capital can be described as the "organizational and managerial abilities" of the business owner (Bruhn et al. 2010). The early literature discusses two important channels through which managerial capital might influence firm performance: Firstly, by influencing the productivity of other input factors (e.g. the way business owners motivate and retain workers), and secondly, by influencing the amount and type of physical and labor inputs (e.g. the decision to hire labor) (Bruhn et al., 2010, p.630).

Classroom trainings provide a cost-effective method to equip businesses owners with the managerial capital needed to successfully manage their firms. Typical findings of business trainings are improvements in business knowledge Karlan and Valdivia, 2011) or implementation of business practices (Bruhn and Zia, 2013) while economically speaking the effects are rather modest (McKenzie and Woodruff, 2013). More effective ways are programs that reduce the comprehensiveness of learning material (Drexler et al. 2014) or initiatives that provide consulting services and find results in the expected direction (Bruhn et al., 2018; Lafortune et al., 2018, Carpena et al. 2019)

\footnotetext{
${ }^{8}$ The summariued reasons for savings constraints mostly rely on the literature that focuses on individuals or households. However, household related reasons for savings constraints are likely directly transferable to the savings constraints of microenterprises or own-account workers. The reason is that business and household finances are closely interrelated and not clearly separated. A typical example is that a majority of business owners do not pay themselves a salary but instead use business sales to finance household expenditures or consumption.
} 


\section{Data}

\subsection{Estimation Sample}

The study uses panel data from a survey of micro and small enterprises in Kampala, Uganda, conducted annually between 2012 and 2017 $!^{9}$ The survey collected detailed information on the enterprise, including finances (sales, costs, savings, borrowing), labor, and business equipment. In addition, a wide range of business owner information were collected, including socio-economic characteristics, financial knowledge, (non)-cognitive abilities, and household information.

As part of the sampling process, administrative areas (zones) with predominant business activity were identified based on interviews with the local administration. Out of these 220 identified business zones within the capital city of Kampala, 21 zones were randomly selected for a door-to-door screening, which resulted in a sampling frame of approximately 5,800 enterprises. The aim of the screening survey was to identify enterprises with up to 10 employees and with a fix location. Finally, a baseline sample of 450 enterprises was drawn with 200 enterprises in each of the retail and the manufacturing sectors and 50 enterprises in the services sector.

The following empirical analysis is based on a panel covering 2013 to 2017. ${ }^{10}$ The estimation sample is restricted to firms that had no change in firm ownership (2 firms dropped). After a further reduction in observations due to missing values on the variables used in the empirical analysis, the final estimation sample comprises 1,487 observations. The number of firms in the estimation sample is 380 in 2013, ultimately falling to 216 in 2017. ${ }^{11}$ An overview of the attrition rates for each wave is in Appendix Table A.1.

\footnotetext{
${ }^{9}$ All waves were collected by the German Institute of Global and Area Studies.

${ }^{10}$ The sample is based on all firms that were in the sample in 2013. The baseline wave of 2012 was omitted because the listing procedure of business equipment changed between 2012 and 2013, which ultimately influences the outcome variables. In 2012, up to 5 pieces of equipment per category were listed, whereas from 2013 onwards, 15 equipment types per category were listed.

${ }^{11}$ The total number of firms interviewed in 2013 was 429.
} 


\subsection{Outcome Variable: Investments}

The outcome variable in the following analysis are investments in business equipment. As part of the survey, the entire business equipment of each firm was listed in each wave. During this procedure, the business equipment was systematically listed according to the categories of tools, furniture, machines, vehicles, land, and other. ${ }^{12}$ Based on this listing, the total value of business equipment (capital stock) of a firm in a given period was calculated ${ }^{13}$ Further, it can be easily distinguished which business equipment has already been in the firm in previous waves and which business equipment is new and, hence, an investment in a particular wave.

The listing of business equipment was very costly in terms of time and there are several reasons to believe that this procedure leads to an accurate measurement of the value of firm investments. Firstly, the survey enumerators were equipped with a list of a firm's business equipment based on the previous wave. They went through this list with the business owner and compared each item with the actual equipment that was present in the business. This approach is supportive in ensuring that all new investments are identified. Secondly, the total value of investments was not based on an estimate of the overall value of all investments purchased since the last round of interviews. Based on observations in the field, it seems easier for respondents to estimate costs for single items than for a bunch of items. Therefore, the survey asks for the value of each single investment that is newly listed with the purpose of obtaining an accurate estimate of the total investment value. Thirdly, any mistakes in the equipment lists that happened during data collection in time period $t$ - 1 were corrected ex-post if detected in time period $t$. This procedure aimed at reducing errors made by enumerators during the listing of equipment to further ensure high data quality. ${ }^{14}$

\footnotetext{
${ }^{12}$ The listing includes information on: year and reason of acquisition, quantity, and replacement value.

${ }^{13}$ The total value of business equipment is defined as the total value of business equipment less accumulated depreciation. During the listing of business equipment, the business owner is asked for the replacement value, which is defined as the value of replacing a specific item considering its actual quality. Hence, the replacement value given by the business owner considers the value loss due to depreciation.

${ }^{14}$ This ex-post correction is critical as recall errors regarding the amount of investments can occur. However, as this system also detects items that were not previously listed, I argue that the gain of listing
} 


\section{[INSERT TABLE 1 ABOUt HeRE]}

Table 1 provides an overview on the development of the value of the entire business equipment (capital stock) and value of investment over time. The average value of the capital stock ranges between 2,521 and 1,832 USD between 2013 and 2017, whereas the average investment value ranges between 113 and 261 USD between 2013 and 2017 15 These numbers show that even though business owners conduct investments, the average value of the capital stock depreciates over time. However, a capital stock which depreciates on average in an economy with an annual GDP growth between 3,58 and 5,18 percent between 2013 and 2017 is rather counterintuitive. One potential explanation for this finding is that the depreciation rates estimated by business owners are too high. The table further shows the share of firms making zero investments in a given period, which ranges between 25 and 52 percent ${ }^{16}$

Another advantage of the detailed listing of business equipment is that it contributes to understanding reasons why firms purchase business equipment. It can be distinguished between investments that extend the number of business equipment (additional investments) and investments that replace old equipment (replacement investments), which is shown in the lower part of Table 1$]^{17}$ As can be seen, additional investments outweigh replacement investments in terms of number of investments conducted but also in terms of total investment value.

\footnotetext{
these missed items outweighs the potential recall error of the investment amount.

${ }^{15}$ To reduce the noise in financial variables, e.g. initial capital stock, the variable is winsorized at the $99^{\text {th }}$ percentile, which means that the top 1 percent values of this variable are replaced with the 99 percentile value of this variable (see Drexler et al. (2014); Bruhn et al. (2018) who apply the same approach). Further, financial variables are deflated to 2012 values given in USD.

${ }^{16}$ Throughout the entire sample period the share of firms making no investments is $15 \%$. Further, $20 \%$ of all firms made investments in one wave, $21 \%$ in two waves, $14 \%$ in three waves, $19 \%$ in four waves and $12 \%$ in all five waves.

${ }^{17}$ These categorizations are identified based on the listing of business equipment. An investment is defined as replacement investment in a specific period, if a new item (e.g. table) is purchased whereby at the same time another item with the same function or purpose that was purchased in a previous year, is no longer listed. Additional investments mean that they are purchased in addition to already existing items of the same functioning or purpose or that they extend the range of products meaning that no such item has been in the business before.
} 


\subsection{Measurement of Constraints}

The explanatory variables of main interest are the obstacles related to credit, savings and managerial constraints. As the constraints cannot be measured directly, the study uses several proxy variables ('items') associated with each constraint. This section describes the measurement of each respective constraint.

Credit Constraints. Regarding the measurement of access to credit, a classification applied by Dinh and Clarke (2012) and Bigsten et al. (2003) that indicates whether an entrepreneur has an unmet demand for credit is adopted. In addition, the data allows for distinguishing between being credit (un-)constrained with regard to formal (banks, microfinance institutions, savings and credit cooperatives (SACCOs)) or informal (friends, relatives, business partners, moneylenders) institutions. The share of credit constrained entrepreneurs ranges between 28 percent for formal and 35 percent for informal (Panel A of Table 2).

\section{[INSERT TABLE 2 ABOUt HeRE]}

According to the definition by Dinh and Clarke (2012) and Bigsten et al. (2003), the group of constrained consists of entrepreneurs who do report need for credit but did not apply for one. Detailed reasons for being categorized as constrained are found in Panel A of Appendix Table A.2. The three most frequently listed reasons are 'feeling uncomfortable' (54 percent formal, 69 percent informal), followed by 'expected rejection' (21 percent formal, 9 percent informal), and 'unfamiliar with process' (10 percent for formal) or 'does not know source' (8 percent for informal). Further reasons are: no formal registration of the business, unable to pay back, and religious reasons. The category of constrained also comprises business owners who applied for a credit but were rejected or did not receive the full amount.

The group of unconstrained consists of those who actually obtained the full amount of credit, those with no need for credit, and those who did not apply as interest rates are too high (see Panel B of Appendix Table A.2). The assignment of 
the latter reason to the group of unconstrained can be questioned and is handled differently in the two studies. Whereas Bigsten et al. (2003) assigned this reason to the group of unconstrained, Dinh and Clarke (2012) do the opposite. ${ }^{18}$

Saving Constraints. To find suitable proxy variables that measure the concept of savings constraints, I take into account the work of Dupas and Robinson (2013a) and Beck et al. (2017) that directly relate the usage of saving devices to business investments. Dupas and Robinson (2013a) evaluate the expansion of bank accounts and find positive effects on total saving amounts and business investments. They argue that formal savings is a device that helps protect money both from the temptation to spend money as well as from demands made by relatives and neighbours, thus resulting in an increase in total savings. I use an indicator whether the respondent has access to a bank account as one proxy to assess whether someone is savings constrained. Panel B of Table 2 shows that around 26 percent of the estimation sample have no access to a bank account.

Beck et al. (2017) address the question whether people reinvest less in their business if they need to protect their savings from consumption commitments of other household members. They find that people who save with others (i.e. people who have 'unprotected savings') are less likely to reinvest into their business compared to people who save individually (either formally or informally). Based on these findings, an index for unprotected savings is constructed taking the value of 1 if the majority of savings are held with a rotating and savings cooperative (ROSCA), at home, or with friends and neighbors 19 This would be people in need to protect their savings from others. In contrast, people who keep most of their savings in a bank account, who save with a savings and credit cooperative (SACCO), or who save using their

\footnotetext{
${ }^{18}$ Bigsten et al. $(2003)$ argue that entrepreneurs who lack the willingness to pay current prices are not rationed. However, they claim that it cannot be ruled out that credits are too expensive.

${ }^{19}$ Keeping the savings with a ROSCA is categorized as unprotected savings. The argument is that the literature links keeping money with a ROSCA to intra-household bargaining problems. This means that individuals rather save with a ROSCA to protect their money, as it would otherwise be unprotected (Anderson and Baland, 2002). One reason why keeping money using this informal saving product reduces investments is that the money saved with a ROSCA cannot be accessed until it is the respondent's turn to receive money.
} 
mobile money account are considered as not having to protect their savings. Panel B in Table 2 shows that around 37 percent do have unprotected savings.

Managerial Constraints. As previously noted, the term managerial capital comprises different concepts, such as the implementation of business practices or the financial literacy level of entrepreneurs. ${ }^{20}$ The business practices taught in standard business training programs typically span around a wide range of topics. Due to survey limitations, this study is only able to control for two business practices: Firstly, whether the business owner keeps business records and secondly, whether the business owner pays himself a salary. These business practices are typically covered by standard business trainings. The necessity of keeping records is covered for example in the training material by Drexler et al. (2014), the International Labour Organization (training material "Start and improve your Business"), and is part of the handbook compiled by Dalton et al. (2019). The importance of paying a fix salary is covered in training material of Drexler et al. (2014).

The survey includes several questions to measure the financial literacy level of the respondent. Among them are also the items used by Lusardi and Mitchell (2014). Panel C in Table 2 gives the share of incorrectly answered financial literacy questions or lack of implemented business practices. As can be seen, there are some financial literacy questions that are answered correctly by the majority of the sample (questions s2, s4 and s6d; see Appendix Table A.3 for the detailed survey questions), while the remaining answers provide more heterogeneity. The bottom of Table 2 shows that 27 percent do not keep any records and that 52 percent do not pay themselves a salary.

To bring together the investment value and proxy variables for each constraint, Table 3 provides average investment values for respondents depending on whether

\footnotetext{
${ }^{20}$ In general, the term managerial capital is representative for a myriad of skills or abilities that are addressed in different business training programs. McKenzie and Woodruff (2013) provide an overview of the 16 typical topics addressed in business training programs. Among these are topics like 'separating household and business finances,' 'inventory management,' and 'employee management.' As the survey does not cover information on all topics, the managerial constraint measured here is limited to selected topics.
} 
specific constraints apply or not. The average investment value for a constraint that applies is found in Column (2), and in Column (4) if it does not apply. Based on all 16 constraints, the average investment value is in 90 percent of the cases lower if a constraint applies compared to if it does not. Restricted to these 90 percent, these differences are in 36 percent of the cases statistically significant. Hence, descriptive evidence suggests that these proxy variables related to the constraints might be associated with lower investments.

\section{[INSERT TABLE 3 ABOUt HERE]}

\subsection{Other Covariates}

In addition to obstacles related to credit, savings, and managerial constraints, several other factors potentially drive a firms' investment value. Table 4 provides descriptive information on the control variables used in the following analyses. The first set of variables characterizes the business owner (Panel A of Table 4). A control for the gender of the business owner is included to account for potential differences in preferences of spending money for business investments or household needs, and to account for different levels of pressure from household members to share income (Jakiela and Ozier, 2016; Fiala, 2017). The estimation is conditioned on the marital status of the respondent to account for intra-household decision making Ashraf, 2009). Further, a control for the age of the business owner is added. The highest educational degree obtained are included to account for correlations between the level of human capital and business investments. Education controls comprise lower educated (no education completed and primary education, covering respondents with up to 7 years of education), medium educated (lower secondary (O-level) degree, which are up to 11 years of education), higher educated (upper secondary (A-level) degree or completed university, which are 13 years of education plus additional 35 years of university education); the last is the reference category. To control for skills and knowledge gathered on-the-job, working experience as measured in years worked in the current business is included. In addition a cognitive ability measure 
based on raven matrices is included. The highest possible score that can be reached is 10. ${ }^{21}$ Further, a control for planned business investment as a proxy for whether the business owner wants the business to grow is included (Dalton et al., 2018).

\section{[INSERT TABle 4 about here]}

Another set of control variables relates to characteristics of the firm (Panel B of Table (4). As theory predicts an inverse relationship between firm age, size, and growth, controls for age and initial firm size are included (Jovanovic, 1982; Evans, 1987). Further, whether the business is run by the owner alone or if the business has employees is also controlled for. As formalization of the business might influence access to finance or training programs and, thus, foster business investments, I control for whether the business is registered with the Ugandan revenue authority. Lastly, controls for the different industry sectors are included. The industries are manufacturing, retail and wholesale, as well as services.22

\section{Empirical Analysis}

This section starts by analyzing which of the obstacles related to credit, savings and managerial constraints are relevant and associated with lower firm investments (Section 4.1). Following this, the determinants of each constraint are analyzed (Section 4.2). As there is ample evidence for heterogeneous treatment effects by gender and educational level, the next section studies if the effects of the afore identified relevant constraints differ with respect to these subgroups (Section 4.3). Lastly, section 4.4 provides a sensitivity analysis.

\footnotetext{
${ }^{21}$ As part of the cognitive ability measure, respondents were given 10 different pictures, each comprising four figures. In each picture, one figure is missing and the respondent has to chose between several possible figures to fill the gap.

${ }^{22}$ The manufacturing industry comprises of the following sectors: manufacture of printing and paper products, textiles and wearing apparel and remaining manufacturing sectors. The retail and wholesale industry comprises of the following sectors: retail and wholesale of electric, phones, household appliances; clothing, footwear and leather; and remaining retail sectors. The services sector mainly covers businesses operating in the hair dressing and beauty business. There is one additional category that covers businesses not falling in one of the aforementioned industry sectors. This category covers between 6 and 17 businesses per wave. The industry sector of manufacturing is used as the reference category.
} 


\subsection{Constraints and Firm Investment}

This section examines which of the sixteen obstacles related to credit, savings and managerial constraints are relevant and associated with lower firm investments. A constraint is defined as relevant if the estimated coefficient is statistically different from zero and negative.

The following analysis starts by examining the correlation between each constraint and the investment value in separate estimations. In a further step, all constraints which have been significant in the aforementioned estimations enter the final model. All estimations control for a rich set of firm and business owner characteristics. A similar procedure of identifying constraints has been used in previous work by Ayyagari et al. (2008) who focus on identifying binding business environment obstacles. A sensitivity analysis shows that an alternative method of selecting relevant constraints which takes into account cross-correlations between constraints yields the same result, this is shown in Section 4.4 .

However, there is a zero effect at the bottom of the distribution (since investments are zero for some firms in certain years as indicated by the summary statistics in Table 1). As the dependent variable is estimated in logarithms, one is added to the number of observations where the outcome value is zero, a similar procedure is applied by (McKenzie, 2017; Criscuolo et al., 2019).

The estimated random effects models are as follow:23

$$
\begin{aligned}
& \log \left(I_{i t}\right)=\alpha_{1}+\alpha_{2} \text { Individual constraint }_{i t}+B_{i t}^{\prime} \alpha_{3}+F_{i t}^{\prime} \alpha_{4}+\epsilon_{i}+u_{i t} \\
& \log \left(I_{i t}\right)=\alpha_{1}+\alpha_{2} \text { All significant constraints }{ }_{i t}+B_{i t}^{\prime} \alpha_{3}+F_{i t}^{\prime} \alpha_{4}+\epsilon_{i}+u_{i t}
\end{aligned}
$$

where, $i$ indexes the enterprise and $t$ indicates the wave. The dependent variable $I_{i t}$ is the value of total investment conducted between wave $t-1$ and $t$. $B_{i t}$ is a vector

\footnotetext{
${ }^{23}$ The consideration of preferring a random-effects model over a fixed effects model stems from the fact that almost all control variables are time invariant.
} 
of control variables related to the business owner and includes indicators for the gender of the respondent, being married, highest educational level, and variables for age, cognitive ability, business experience, and planned investments. $F_{i t}$ is a vector of firm characteristics and comprises variables such as years since the establishment of the business, initial capital stock value, and indicators for whether the business is operating without employees (own-account worker), the firm being registered with the revenue authority, and industry sectors. To take into account the panel dimension of the data, indicators for each wave are included. $\epsilon_{i}$ is the business-specific error and $u_{i t}$ is the idiosyncratic error.

As this empirical analysis also examines time-constant determinants of constraints (see Section 4.2), the estimation relies on a random effects approach. To address the concerns of random effects models, it is accounted for a detailed set of controls in order to reduce the potential for unobserved heterogeneity to confound the estimates.

The individual constraints that enter the estimation comprise obstacles related to capital constraints (being (in)-formal credit constrained), savings constraints (having no bank account, and unprotected savings) and managerial constraints (incorrect answers to financial literacy questions (see Appendix Table A.3 for an overview on all questions) and whether business practices are not implemented such as record keeping, and whether the business owner pays himself a salary).

The estimation results are reported in Table 5. Columns 1-16 present the relationship between each single constraint and the investment value (equation 1). The model presented in Column 17 only includes relevant obstacles which have a negative and significant impact on investments (equation 2). Full estimation results are reported in Appendix Table A.4

\section{[INSERT TABle 5 ABOUt HeRE]}

The correlations between each individual obstacle and the investment value in Columns (1) - (16) of Table 5 indicate that only unprotected savings (related to 
savings constraints) and no record keeping (related to managerial constraints) have a negative and significant coefficient. Including both constraints in one estimation shows that while the magnitude of the estimated effects diminish, their impact on investment is still negative and significant (Column (17) of Table 5). Specifically, investments of individuals who have unprotected savings are 31 percent lower, and investments of business owners who do not keep records are approximately 36 percent lower 24

In general, the results indicate that out of 16 obstacles, having unprotected savings and no record keeping are the primary constraints which are relevant regarding firm investment in the present setting. In addition, the size of the estimated coefficients stresses the economic importance of relevant constraints for firm investments.

\subsection{Determinants of Constraints}

This section contributes to the understanding on the determinants of each relevant constraint. Important socio-economic and firm characteristics associated with each constraint are identified based on the following estimation equation:

$$
\text { Constraint }_{i t}=\beta_{1}+B_{i t}^{\prime} \alpha_{2}+F_{i t}^{\prime} \alpha_{3}+\epsilon_{i t}
$$

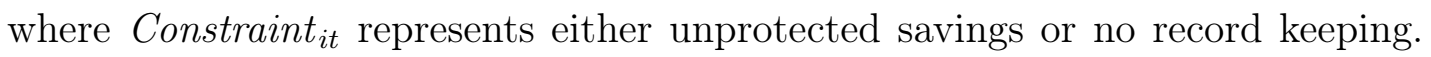
$B_{i t}$ and $F_{i t}$ are again vectors for business owner and firm characteristics. Results of the estimated random effects models are reported in Table 6. As both dependent variables are binary, a robustness analysis assesses the sensitivity of the estimated random effects model to alternative models and shows that coherences between control variables and constraints do not differ depending on estimating a random effects, random effects logit or probit model (see Appendix Table A.5.

\section{[INSERT TABle 6 about Here]}

\footnotetext{
${ }^{24}$ It seems reasonable to examine if there is an additional (negative) effect on investments if both constraints are binding at the same time. However, additionally including an interaction term in the above estimation does not show any additional effects.
} 
The first column of Table 6 shows the determinants associated with a higher likelihood of having unprotected savings. Regarding differences by gender, the results suggest that women are more likely to save with others, and are as a consequence in need to protect their savings. A similar pictures emerges for respondents with less years of education or lower ability business owners, as can be seen from an increasing likelihood of having unprotected savings with decreasing formal school education and lower levels of cognitive ability. Similarly, the results suggest an inverse relationship between business experience and having unprotected savings. Regarding firm characteristics, business owners who run their business without employees are also associated of having more likely unprotected savings

The second column of Table 6 investigates the determinants of no record keeping in the business. All variables related to higher education, ability, and experience running a business suggest a negative association with record keeping. The larger the business (measured as initial capital stock), if the business is formal (registered with revenue authority) and having employees are characteristics that point towards a higher likelihood that records are kept in the business.

\subsection{Heterogeneity Analysis}

The following section analyzes whether the impact of relevant constraints on investment differs with respect to heterogeneous groups. The focus is on differences with respect to gender (Table 7) and educational level (Table 8).

\section{[INSERT TABle 7 ABOUt HeRE]}

For reasons of comparison, Column (1) of Table 7 provides again the main estimation results (as shown previously in Column 17 of Table 5), followed by an estimation including the interaction between both relevant constraints with an indicator of the respondent of being a women (Column (2)) and the remaining columns show estimates in a sample split for women only (Column (3)) and men only (Column (4)). 
The findings suggest that business investments by women and men are not differentially affected by any of the constraints, as indicated by the interaction terms in Panel A of Table 7. At the same time, point estimates indicate that unprotected savings and no record keeping are rather associated with lower investments for men and women, however, the analysis does not provide statistically significant support (see estimated marginal effects in Panel B of Table 7).

Table 8 investigates heterogeneous effects by educational level. Again, main results are reported in Column (1), Column (2) shows a model that includes interaction terms between constraints and indicators for educational levels, and the remaining columns show estimates in a sample split for lower educated (Column (3)), medium educated (Column (4)) and higher educated (Column (5)).

\section{[INSERT TABle 8 about HeRe]}

The results suggest that the effect of businesses which do not keep records on investments is more negative the lower the business owners educational level. Panel A shows that interactions between no record keeping and lower (up to primary education) or medium (lower secondary degree) educational levels, respectively, are negative and differ significantly compared to the reference group of higher educated (upper secondary degree or university degree) (Column (2) of Panel A). Total marginal effects for no record keeping by educational level are shown in Panel B. Specifically the marginal effect for lower educated is -0.49 and -0.76 for medium educated, both estimates being highly significant $(\alpha=0.05)$. These estimates are lower compared to the higher educated $(0.34)$ or to the overall sample estimate of -0.36 (Column (1) of Panel A). These results are in line with estimations based on sample splits in Columns (3-5). For unprotected savings, no differences between educational levels are found.

A sensitivity analysis shows that effects are not driven by the chosen categorizations of educational levels. Results point in the same direction even if the group of medium educated comprises additionally the group of upper secondary educated 
(A-level degree): the marginal effect of record keeping is still significantly lower for medium and lower educated compared to higher educated (Appendix Table A.6. Columns (1)-(4)). Similarly, interacting the relevant constraints with an indicator for each separate educational level supports the finding that the effect is lower for primary and lower secondary educated compared to university educated respondents (Appendix Table A.6, Columns (5)-(9)).

The present heterogeneity analysis focuses in detail on the most conventional studied characteristics which are groups with different educational levels or by gender. However, to provide a complete picture a comprehensive heterogeneity analyses is conducted with respect to the control variables related to business owner characteristics (married, age, cognitive ability, investments, business experience) and firm characteristics (industry sector, own-account worker, firm age and business registration). The effect of both constraints seem to be especially (negative) pronounced for the following subgroups: respondents who are not married, business owners who work in the services sector or firms which are not registered. Results can be found in Appendix Tables A.7 and A.8.

Combining the findings from the main analysis in Section 4.1 and the results found in the heterogeneity analysis suggests that even though overall findings show a negative association between unprotected savings and no record keeping in the overall sample, constraints are not equally important for all subgroups. Instead, it is important to take the educational level of respondents into account.

Investments differ significantly between educational levels in the present sample. Average investments of lower and medium educated are with 273 USD and 431 USD below the sample average (463 USD), and higher educated invest around two thirds more (737 USD). Even if the present analysis cannot establish causality, the results should be taken as important indication that these constraints may matter for specific groups. 


\subsection{Sensitivity Analysis}

This section probes the sensitivity of the results to changes in the empirical specification and inclusion of further control variables. The following issues are addressed: (i) selection of relevant constraints that takes into account correlations between constraints; (ii) pooled ordinary least squares model as alternative to the random effects model; (iii) controlling for past randomized controlled trials; (iv) restricting the sample to strictly positive investment values; and (v) explaining the incidence of investments.

\section{[INSERT TABle 9 ABOUt HeRE]}

Firstly, an alternative selection method of identifying relevant constraints is applied, which takes into account the correlation between constraints. Essentially, this method yields the same result as applied in Table 5, which is that unprotected savings and record keeping are identified as key constraints. The alternative selection model, starts with a model that controls for all 15 constraints at the same time which bears the advantage, that cross-correlations between constraints are taken into account, this is provided in Column (1) of Table 9. Thereupon, irrelevant constraints (marked in cells highlighted in grey) are successively removed based on highest p-values. Finally Column (15) yields a model with significant constraints only, which is identical to the model presented in Column (17) of Table 5.

\section{[Insert TABle 10 about HeRE]}

Secondly, I re-estimate the model using a pooled ordinary least-squares (OLS) estimation (Column (1)). Results of the pooled OLS model are very similar to the initial specification in Column (17) of Table 5. Thirdly, in April 2013 and 2016, randomized controlled trials were conducted with respondents of the present sample ${ }^{25}$ To show that past interventions do not alter the estimation results, an estimation that controls for these interventions is conducted. Comparing results in Column (2)

\footnotetext{
${ }^{25}$ In April 2013, 245 entrepreneurs received a money transfer of 300,000 UGX (116 USD) and, in April 2016, respondents received information about the importance of marketing.
} 
with the main estimation results in Column (17) of Table 5 shows that the magnitude as well as the significance of the coefficients is very similar. Fourthly, as there are some businesses that do not conduct any investments in a given period, I restrict the sample to only positive investments in a given period. Column (3) shows that the estimated coefficients for savings and managerial constraints do not change significantly. Lastly, Column (4) shows an estimation of constraints on the incidence of investment, meaning the decision to make an investment in a specific period. The results show, that the constraints do not affect whether any investment is undertaken, but only by how much. This is consistent with constraints only impacting on the speed with which firms can reach their desired size.

\section{Conclusion}

Micro and small enterprises (MSEs) are currently the main employers outside of agriculture in developing countries. Against the backdrop of considerable expected population growth and a dearth of formal jobs, especially in Africa, studying the growth performance and investment constraints of MSEs is of prime policy importance.

This paper analyzes which types of businesses benefit from an intervention seeking to alleviate obstacles related to credit, savings and managerial constraints. Using a five-year panel dataset of MSEs, this study analyzes in a first step which constraints matter for firm investment and shows that two obstacles are associated with lower investments: saving with others (and, hence, the need to protect own savings) and no record keeping. In a second step the analysis shows that business owners with lower education, ability, experience; and firms operating without employees are characteristics significantly associated with both constraints. The core of the analysis investigates whether constraints have a similar impact on business investments for different subgroups. The focus is on subgroups by educational level and gender. Results show that investments are significantly smaller for the lower 
or medium educated business owners who do not keep records as compared to the higher educated. The same pattern is observed for unprotected savings. However, both constraints have similar impacts on investments for women and men.

The present analysis is based on a selected sample of MSEs in Kampala, Uganda which likely shares many characteristics with other firms in Uganda and in other low-income countries in Africa. However, interpreting the results of the present study and discussing the policy implications, it should be kept in mind that the results provided are correlations and not causal findings and that potential reverse causality concerns cannot be ruled out.

The starting point of the present analysis has been the frequent observation of heterogeneous treatment effects in studies aiming to alleviate specific constraints using targeted interventions. The present results underpin on the one hand that not all groups (here: different levels of education) are affected by a specific constraint (here: record keeping) to the same extent. On the other hand, the analysis provides a straightforward approach to diagnose subgroups with specific constraints (here: lower and medium educated). This can be used as a basis prior to treatment assignment, as suggested by Fischer and Karlan (2015).

A crucial question is how the procedure of preselecting businesses can be applied in practice? One option is to select micro and small businesses owners based on the identified characteristics found in this study. However, if the assumption is that firms with specific characteristics might face different constraints in a different setting (e.g. different country, cultural setting, industry sector), one alternative could be to collect information on the proxy variables used in the present study and to rerun the analysis. This is less time and cost-intensive than collecting an entire in-depth survey. 


\section{References}

Anderson, S. and BAland, J.-M. (2002). The economics of roscas and intrahousehold resource allocation. Quarterly Journal of Economics, 117 (3), 963-995.

Ashraf, N. (2009). Spousal control and intra-household decision making: An experimental study in the Philippines. American Economic Review, 99 (4), 1245-77.

Ayyagari, M., Demirguc-Kunt, A. and Maksimovic, V. (2008). How important are financing constraints? The role of finance in the business environment. World Bank Economic Review, 22 (3), 483-516.

_- _ - and - (2017). SME finance. Policy Research Working Paper, No. 8241, Washington, D.C. : World Bank Group.

Banerjee, A. V. and Duflo, E. (2005). Growth theory through the lens of development economics. In P. Aghion and S. Durlauf (eds.), Handbook of Economic Growth, vol. 1, Part A, Elsevier, pp. 473-552.

- and - (2007). The economic lives of the poor. Journal of Economic Perspectives, 21 (1), 141-168.

- and - (2014). Do firms want to borrow more? Testing credit constraints using a directed lending program. Review of Economic Studies, 81 (2), 572-607.

Beck, T., Pamuk, H. and URAs, B. R. (2017). Entrepreneurial saving practices and reinvestment: Theory and evidence. Review of Development Economics, 21 (4), 1205-1228.

Bigsten, A., Collier, P., Dercon, S., Fafchamps, M., Gauthier, B., GunNing, J. W., Oduro, A., Oostendorp, R., PAtillo, C., Söderbom, M. et al. (2003). Credit constraints in manufacturing enterprises in Africa. Journal of African Economies, 12 (1), 104-125.

Buorvatn, K. and Tungodden, B. (2010). Teaching business in Tanzania: Evaluating participation and performance. Journal of the European Economic Association, 8 (2-3), 561-570.

Bloom, N., Mahajan, A., McKenzie, D. and Roberts, J. (2010). Why do firms in developing countries have low productivity? American Economic Review, 100 (2), 619-623.

Bruhn, M., Karlan, D. and Schoar, A. (2010). What capital is missing in developing countries? American Economic Review, 100 (2), 629-633.

—, - and - (2018). The impact of consulting services on small and medium enterprises: Evidence from a randomized trial in Mexico. Journal of Political Economy, 126 (2), 635-687.

- and ZiA, B. (2013). Stimulating managerial capital in emerging markets: The impact of business training for young entrepreneurs. Journal of Development Effectiveness, 5 (2), 232-266.

Burgess, R. and Pande, R. (2005). Do rural banks matter? Evidence from the Indian social banking experiment. American Economic Review, 95 (3), 780-795. 
- , - and Wong, G. (2005). Banking for the poor: Evidence from India. Journal of the European Economic Association, 3 (2-3), 268-278.

Calderone, M., Fiala, N., Mulaj, F., Sadhu, S. and Sarr, L. (2018). Financial education and savings behavior: Evidence from a randomized experiment among low-income clients of branchless banking in India. Economic Development and Cultural Change, 66 (4), 793-825.

Carpena, F., Cole, S., Shapiro, J. and Zia, B. (2019). The abcs of financial education: Experimental evidence on attitudes, behavior, and cognitive biases. Management Science, 65 (1), 346-369.

Criscullo, C., Martin, R., Overman, H. G. and Van Reenen, J. (2019). Some causal effects of an industrial policy. American Economic Review, 109 (1), 48-85.

Dalton, P. S., Rueschenpoehler, J., Uras, B. and Zia, B. (2019). Learning to Grow from Peers: Experimental Evidence from Small Retailers in Indonesia. Tech. rep.

-, Ruschenpohler, J. and ZiA, B. (2018). Determinants and dynamics of business aspirations. World Bank Policy Research Working Paper, No. 8400.

De MeL, S. and McKenzie, D. (2011). Getting credit to high return microentrepreneurs. World Bank Economic Review, 25 (3), 456-485.

- - - and Woodruff, C. (2008). Returns to capital in microenterprises: Evidence from a field experiment. Quarterly Journal of Economics, 123 (4), 1329-1372.

Dinh, H. T. and Clarke, G. R. G. (2012). Performance of Manufacturing Firms in Africa. The World Bank.

Drexler, A., Fischer, G. and SchoAr, A. (2014). Keeping it simple: Financial literacy and rules of thumb. American Economic Journal: Applied Economics, $6(2), 1-31$.

Dupas, P. and Robinson, J. (2013a). Savings constraints and microenterprise development: Evidence from a field experiment in Kenya. American Economic Journal: Applied Economics, 5 (1), 163-192.

— and - (2013b). Why don't the poor save more? evidence from health savings experiments. American Economic Review, 103 (4), 1138-71.

Evans, D. (1987). The relationship between firm growth, size, and age: Estimates for 100 manufacturing industries. Journal of Industrial Economics, 35 (4), 567-81.

Fafchamps, M., McKenzie, D., Quinn, S. and Woodruff, C. (2014). Microenterprise growth and the flypaper effect: Evidence from a randomized experiment in ghana. Journal of Development Economics, 106, 211-226.

FiAla, N. (2017). Business is tough, but family is worse: Household bargaining and investment in microenterprises in Uganda. Working papers 2017-05, University of Connecticut, Department of Economics.

Fischer, G. and Karlan, D. (2015). The catch-22 of external validity in the context of constraints to firm growth. American Economic Review, 105 (5), 29599 . 
Gine, X. and Mansuri, G. (2014). Money or ideas? A field experiment on constraints to entrepreneurship in rural Pakistan. Tech. rep., Washington, DC.: World Bank.

Jakiela, P. and Ozier, O. (2016). Does Africa need a rotten kin theorem? Experimental evidence from village economies. Review of Economic Studies, 83 (1), $231-268$

Jovanovic, B. (1982). Selection and the evolution of industry. Econometrica, 50 (3), 649-670.

Karlan, D., Ratan, A. and Zinman, J. (2014). Savings by and for the poor: A research review and agenda. Review of Income and Wealth, 60 (1), 36-78.

- and VAldivia, M. (2011). Teaching entrepreneurship: Impact of business training on microfinance clients and institutions. Review of Economics and Statistics, 93 (2), 510-527.

Kendall, J., Mylenko, N. and Ponce, A. (2010). Measuring financial access around the world. Policy Research Working Paper, No. 5253, Washington, DC.: World Bank.

Kinda, J. L., Tidiane Loening (2008). Small enterprise growth and the rural investment climate: Evidence from Tanzania. African Development Review, 22 (1), $173-207$.

Lafortune, J., Riutort, J. and Tessada, J. (2018). Role models or individual consulting: The impact of personalizing micro-entrepreneurship training. American Economic Journal: Applied Economics, 10 (4), 222-245.

Lusardi, A. and Mitchell, O. S. (2014). The economic importance of financial literacy: Theory and evidence. Journal of Economic Literature, 52 (1), 5-44.

MCKenzIE, D. (2017). Identifying and spurring high-growth entrepreneurship: Experimental evidence from a business plan competition. American Economic Review, 107 (8), 2278-2307.

- and Woodruff, C. (2008). Experimental evidence on returns to capital and access to finance in Mexico. World Bank Economic Review, 22 (3), 457-482.

— and - (2013). What are we learning from business training and entrepreneurship evaluations around the developing world? World Bank Research Observer, 29 (1), 48-82.

Nichter, S. and Goldmark, L. (2009). Small firm growth in developing countries. World Development, 37 (9), 1453-1464.

PRINA, S. (2015). Banking the poor via savings accounts: Evidence from a field experiment. Journal of Development Economics, 115, 16-31.

Sleuwaegen, L. and Goedhuys, M. (2002). Growth of firms in developing countries, evidence from Cote d'Ivoire. Journal of Development Economics, 68 (1), $117-135$.

Steinert, J. I., Zenker, J., Filipiak, U., Movsisyan, A., Cluver, L. D. and Shenderovich, Y. (2018). Do saving promotion interventions increase household savings, consumption, and investments in Sub-Saharan Africa? A systematic review and meta-analysis. World Development, 104, 238-256. 
The Republic of UGanda (2014). Ugandas employment challenge.

Woodruff, C. (2018). Addressing constraints to small and growing businesses. Tech. rep., International Growth Centre. 
Table 1: Summary Statistics on Capital Stock and Investment

\begin{tabular}{|c|c|c|c|c|c|c|c|c|c|c|}
\hline & (1) & $(2)$ & $\overline{(3)}$ & $(4)$ & $(5)$ & $(6)$ & (7) & $\overline{(8)}$ & $(9)$ & $(10)$ \\
\hline & \multicolumn{2}{|c|}{2013} & \multicolumn{2}{|c|}{2014} & \multicolumn{2}{|c|}{2015} & \multicolumn{2}{|c|}{2016} & \multicolumn{2}{|c|}{2017} \\
\hline & $\mathrm{n}$ & mean & $\mathrm{n}$ & mean & $\mathrm{n}$ & mean & $\mathrm{n}$ & mean & $\mathrm{n}$ & mean \\
\hline Capital stock & 380 & 2521.12 & 347 & 2079.36 & 292 & 2368.38 & 252 & 1997.5 & 216 & 1832.03 \\
\hline Investment & 380 & 161.69 & 347 & 194.76 & 292 & 180.90 & 252 & 113.68 & 216 & 261.21 \\
\hline Investment $($ share $=0)$ & 197 & 0.52 & 107 & 0.31 & 114 & 0.39 & 97 & 0.38 & 54 & 0.25 \\
\hline Investment & 183 & 335.75 & 240 & 281.59 & 178 & 296.76 & 155 & 184.82 & 162 & 348.28 \\
\hline Additional & 172 & 335.56 & 213 & 257.50 & 168 & 296.81 & 146 & 184.14 & 117 & 330.03 \\
\hline Replacement & 23 & 161.96 & 58 & 219.55 & 25 & 118.41 & 31 & 56.85 & 101 & 176.31 \\
\hline
\end{tabular}

Source: Survey on micro and small enterprises in Uganda, waves 2013-2017, own calculations. Summary statistics based on estimation sample.

Notes: All values are in USD. The first row gives the average capital stock, which is the total value of business equipment at the time of the survey. Row two gives the total amount of investments conducted in the last 12 months prior to the survey interview and row three provides the share of businesses that did not conduct any investment in a given wave. Row four shows the total investment value of strictly positive investments only and the last two rows show the total investment amount separate by additional and replacement investments. Additional investments are investments that extend the number of products in a business (row five) and replacement investments are new items that replace old items which are not part of the capital stock any more (row six). 
Table 2: Summary Statistics on Obstacles related to Credit, Savings and Managerial Constraints

\begin{tabular}{|c|c|}
\hline & share \\
\hline \multicolumn{2}{|l|}{ A. Credit Constraints ${ }^{a}$} \\
\hline Formal credit constrained & 0.28 \\
\hline Informal credit constrained & 0.35 \\
\hline \multicolumn{2}{|l|}{ B. Savings Constraints ${ }^{b}$} \\
\hline No bank account & 0.26 \\
\hline Unprotected savings & 0.37 \\
\hline \multicolumn{2}{|l|}{ C. Managerial Constraints ${ }^{c}$} \\
\hline \multicolumn{2}{|l|}{ Financial Literacy } \\
\hline Gift sharing (s2) & 0.06 \\
\hline Inflation (s3) & 0.35 \\
\hline Zero interest (s4) & 0.02 \\
\hline Interest (s5a) & 0.56 \\
\hline Compound interest (s5b) & 0.36 \\
\hline Statement: high return $(\mathrm{s} 6 \mathrm{a})$ & 0.19 \\
\hline Statement: inflation (s6b) & 0.10 \\
\hline Statement: risk diversification (s6c) & 0.23 \\
\hline Statement: agreement (s6d) & 0.05 \\
\hline Discount (s7) & 0.22 \\
\hline \multicolumn{2}{|l|}{ Business Practices } \\
\hline No record keeping & 0.27 \\
\hline No fix salary & 0.52 \\
\hline
\end{tabular}

Source: Survey on micro and small enterprises in Uganda, waves 2013-2017, own calculations. Summary statistics based on estimation sample.

Notes:

a Detailed information on reasons for being credit (un)constrained can be found in Appendix Table A.2 $b$ No bank account gives the share of businesses not having a bank account. Unprotected savings gives the share of people that need to protect their savings of others. The higher the shares the more are constrained.

c Managerial constraints capture obstacles related to financial literacy skills, measured using financial literacy questions, and implemented business practices. An overview of the financial literacy questions used is provided in Appendix Table A.3 Business practices comprise whether the business owner does not keep records in the business and whether the business owner pays herself a fix salary. 
Table 3: Summary Statistics on Investments by Constraints

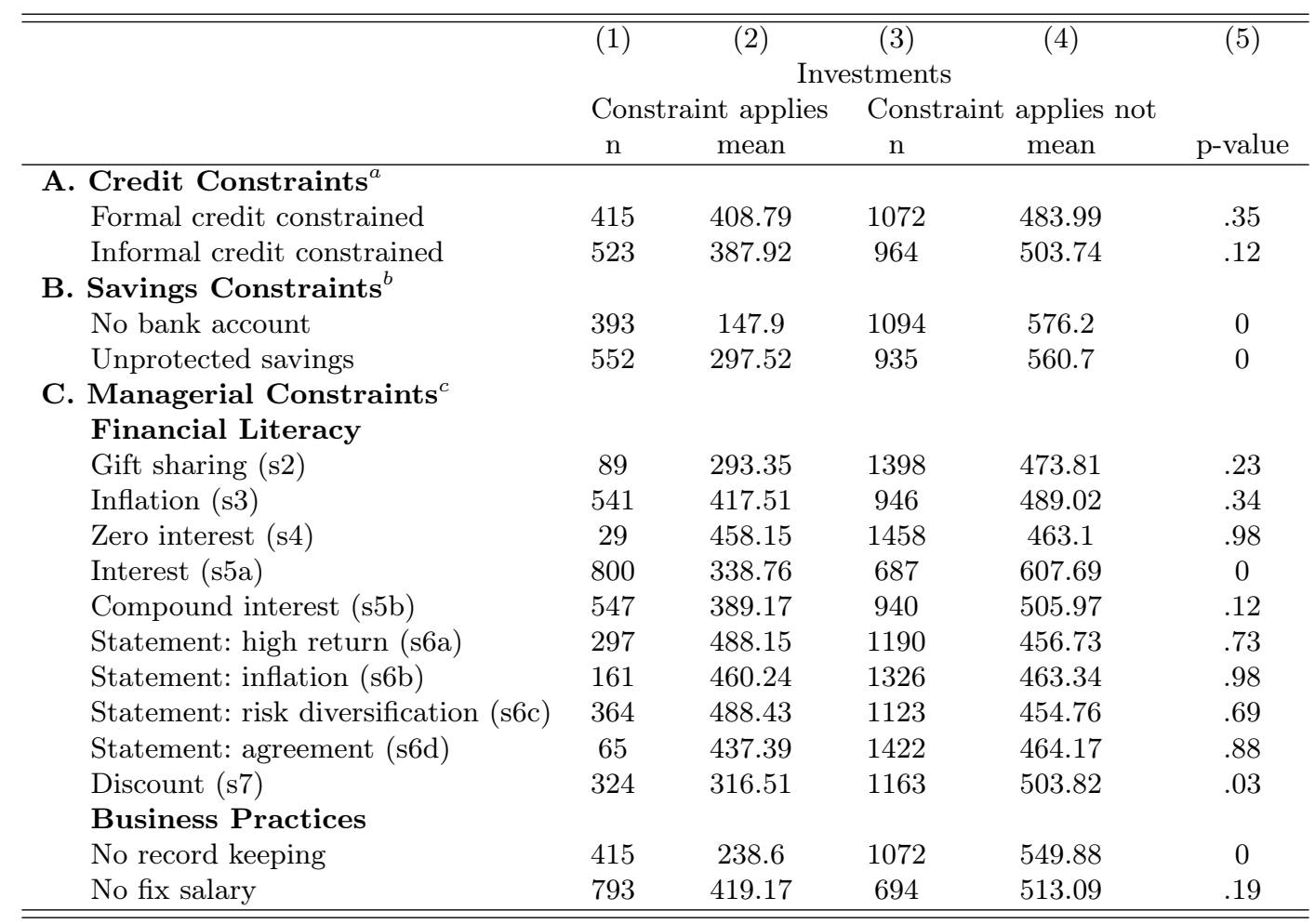

Source: Survey on micro and small enterprises in Uganda, waves 2013-2017, own calculations. Summary statistics refer to the estimation sample.

Notes: The table shows average investments in case a constraint applies (Column (2)) or does not apply (Column (4)). To provide an example: the average investment value for respondents who are formal credit constrained is 409 USD, and it is 484 USD for those who are not formal credit constrained. Regarding financial literacy questions, the columns give the average investment in case a question (e.g. gift sharing (s2)) is answered wrongly (293 USD) or answered correctly (474 USD). Column (5) provides the p-value of a mean comparison test between Column (2) and (4). 
Table 4: Summary Statistics on Explanatory Variables

\begin{tabular}{lllcll}
\hline \hline & $(1)$ & $(2)$ & $(3)$ & $(4)$ & $\begin{array}{c}(5) \\
\max \end{array}$ \\
& mean & sd & median & min & \\
\hline A. Socio-economic characteristics & & & & & \\
Female & 0.42 & $(0.49)$ & {$[0.00]$} & 0.00 & 1.00 \\
Married & 0.62 & $(0.49)$ & {$[1.00]$} & 0.00 & 1.00 \\
Age & 36.84 & $(9.42)$ & {$[35.00]$} & 19.00 & 74.00 \\
Lower educated & 0.42 & $(0.49)$ & {$[0.00]$} & 0.00 & 1.00 \\
Medium educated & 0.26 & $(0.44)$ & {$[0.00]$} & 0.00 & 1.00 \\
Higher educated (ref.) & 0.32 & $(0.47)$ & {$[0.00]$} & 0.00 & 1.00 \\
Business experience & 9.30 & $(6.79)$ & {$[7.00]$} & 0.00 & 42.00 \\
Cognitive ability (raven score) & 6.09 & $(2.56)$ & {$[6.00]$} & 0.00 & 10.00 \\
Planned investment & 0.84 & $(0.37)$ & {$[1.00]$} & 0.00 & 1.00 \\
B. Firm characteristics & & & & & \\
Age of firm & 9.64 & $(6.91)$ & {$[8.00]$} & 0.00 & 42.00 \\
Initial capital (USD) & 4367.16 & $(54554.60)$ & {$[609.61]$} & 2.32 & $2.05 \mathrm{e}+06$ \\
Own-account worker & 0.45 & $(0.50)$ & {$[0.00]$} & 0.00 & 1.00 \\
Registered with Revenue Authority & 0.18 & $(0.39)$ & {$[0.00]$} & 0.00 & 1.00 \\
Hair dressing and beauty (ref.) & 0.13 & $(0.33)$ & {$[0.00]$} & 0.00 & 1.00 \\
Manufacturing (printing, paper) & 0.13 & $(0.33)$ & {$[0.00]$} & 0.00 & 1.00 \\
Manufacturing (textile) & 0.13 & $(0.34)$ & {$[0.00]$} & 0.00 & 1.00 \\
Manufacturing (remaining) & 0.24 & $(0.42)$ & {$[0.00]$} & 0.00 & 1.00 \\
Retail and Wholesale (remaining) & 0.19 & $(0.39)$ & {$[0.00]$} & 0.00 & 1.00 \\
Retail and Wholesale (retail, clothing) & 0.09 & $(0.29)$ & {$[0.00]$} & 0.00 & 1.00 \\
Retail and Wholesale (electric, phones) & 0.06 & $(0.25)$ & {$[0.00]$} & 0.00 & 1.00 \\
Remaining sectors & 0.03 & $(0.18)$ & {$[0.00]$} & 0.00 & 1.00 \\
\hline \hline
\end{tabular}

Source: Survey on micro and small enterprises in Uganda, waves 2013-2017, own calculations. Summary statistics refer to the estimation sample.

Notes: The table provides summary statistics of the socio-economic characteristics of the business owner and characteristics of the firm. Variables indicated with (ref.) are reference categories in the estimations. The level of education is categorized as follows: lower educated comprise those who have no education, started or completed primary education; medium educated comprise respondents having a lower secondary degree (O-level education), and higher educated comprise respondents having a upper secondary degree (A-level education) or completed university. 


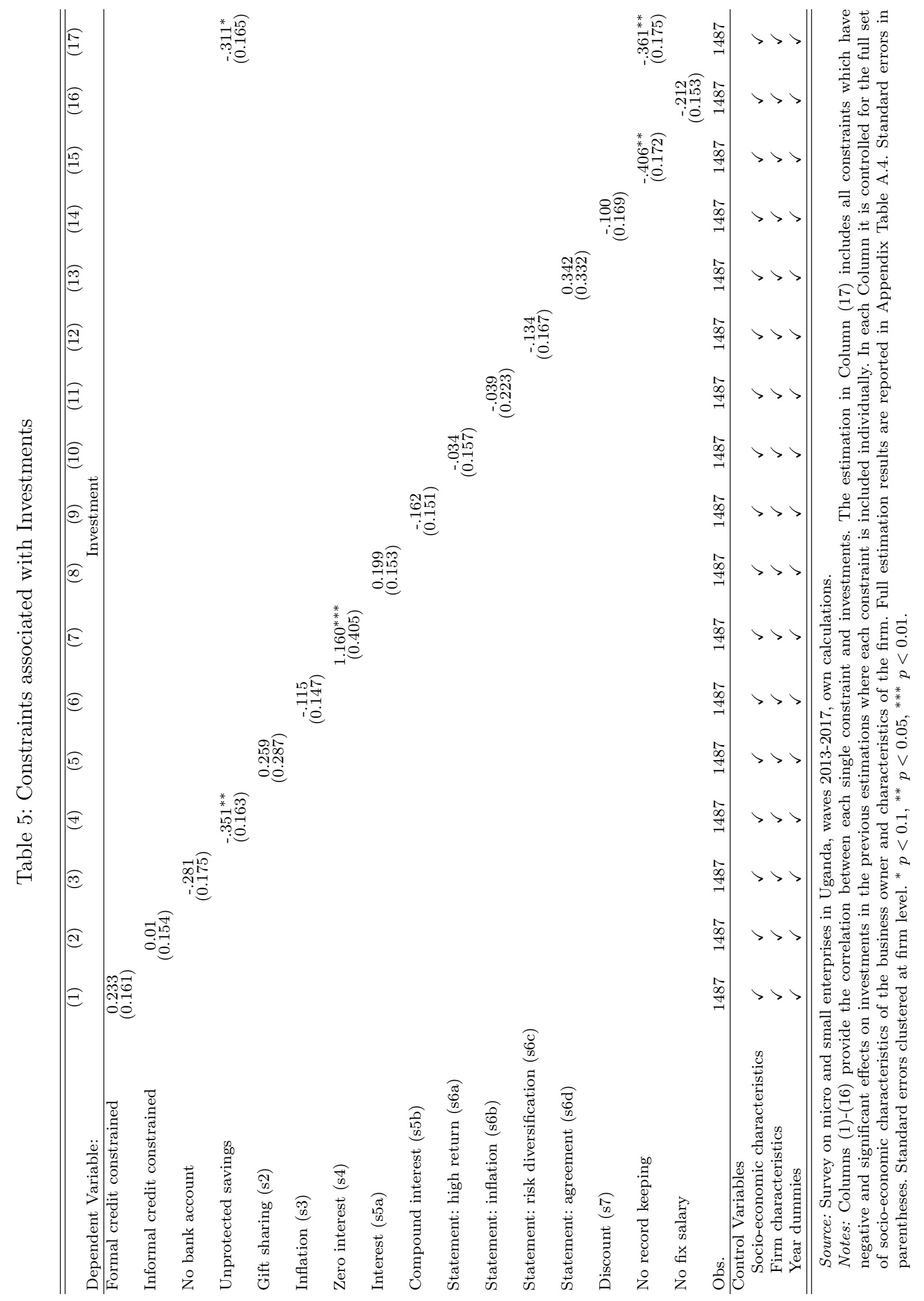


Table 6: Determinants of Constraints

\begin{tabular}{|c|c|c|}
\hline Dependent Variables: & $\begin{array}{c}\text { (1) } \\
\text { Unprotected savings }\end{array}$ & $\begin{array}{c}(2) \\
\text { No record keeping }\end{array}$ \\
\hline Women & $\begin{array}{l}0.066^{*} \\
(0.037)\end{array}$ & $\begin{array}{l}-.049 \\
(0.037)\end{array}$ \\
\hline Married & $\begin{array}{l}-.023 \\
(0.03)\end{array}$ & $\begin{array}{c}0.015 \\
(0.022)\end{array}$ \\
\hline Age & $\begin{array}{l}-.008 \\
(0.012)\end{array}$ & $\begin{array}{l}-.007 \\
(0.01)\end{array}$ \\
\hline Age squared & $\begin{array}{c}0.0001 \\
(0.0002)\end{array}$ & $\begin{array}{l}0.00007 \\
(0.0001)\end{array}$ \\
\hline Lower educated & $\begin{array}{c}0.159^{* * *} \\
(0.042)\end{array}$ & $\begin{array}{l}0.186^{* * *} \\
\quad(0.04)\end{array}$ \\
\hline Medium educated & $\begin{array}{c}0.124^{* * *} \\
(0.039)\end{array}$ & $\begin{array}{c}0.086^{* *} \\
(0.041)\end{array}$ \\
\hline Cognitive ability (raven score) & $\begin{array}{l}-.012^{*} \\
(0.007)\end{array}$ & $\begin{array}{c}-.018^{* * *} \\
(0.006)\end{array}$ \\
\hline Business experience & $\begin{array}{r}-.013^{* *} \\
(0.005)\end{array}$ & $\begin{array}{l}-.012^{*} \\
(0.007)\end{array}$ \\
\hline Planned investment & $\begin{array}{l}-.031 \\
(0.033)\end{array}$ & $\begin{array}{l}-.041 \\
(0.026)\end{array}$ \\
\hline Age of firm & $\begin{array}{c}0.007 \\
(0.008)\end{array}$ & $\begin{array}{c}0.01 \\
(0.009)\end{array}$ \\
\hline Age of firm squared & $\begin{array}{l}0.00006 \\
(0.0002)\end{array}$ & $\begin{array}{l}1.00 \mathrm{e}-05 \\
(0.0002)\end{array}$ \\
\hline Initial capital stock (USD) & $\begin{array}{c}3.62 \mathrm{e}-07^{* * *} \\
(1.09 \mathrm{e}-07)\end{array}$ & $\begin{array}{c}-1.05 \mathrm{e}-07^{*} \\
(5.35 \mathrm{e}-08)\end{array}$ \\
\hline Own-account worker & $\begin{array}{c}0.058^{* *} \\
(0.029)\end{array}$ & $\begin{array}{c}0.119^{* * *} \\
(0.027)\end{array}$ \\
\hline Registered with revenue authority & $\begin{array}{l}-.011 \\
(0.033)\end{array}$ & $\begin{array}{c}-.116^{* * *} \\
(0.025)\end{array}$ \\
\hline Manufacturing (printing, paper) & $\begin{array}{l}-.073 \\
(0.063)\end{array}$ & $\begin{array}{l}-.094 \\
(0.065)\end{array}$ \\
\hline Manufacturing (textile) & $\begin{array}{l}-.032 \\
(0.065)\end{array}$ & $\begin{array}{l}-.035 \\
(0.07)\end{array}$ \\
\hline Manufacturing (remaining) & $\begin{array}{l}-.052 \\
(0.059)\end{array}$ & $\begin{array}{c}-.231^{* * *} \\
(0.06)\end{array}$ \\
\hline Retail and Wholesale (remaining) & $\begin{array}{l}-.022 \\
(0.06)\end{array}$ & $\begin{array}{l}-.120^{*} \\
(0.062)\end{array}$ \\
\hline Retail and Wholesale (retail, clothing) & $\begin{array}{l}-.103 \\
(0.072)\end{array}$ & $\begin{array}{l}-.161^{* *} \\
(0.067)\end{array}$ \\
\hline Retail and Wholesale (electric, phones) & $\begin{array}{l}-.010 \\
(0.077)\end{array}$ & $\begin{array}{r}-.138^{* *} \\
(0.068)\end{array}$ \\
\hline Remaining sectors & $\begin{array}{l}-.172^{* *} \\
(0.079)\end{array}$ & $\begin{array}{l}-.082 \\
(0.071)\end{array}$ \\
\hline Year 2014 & $\begin{array}{c}0.011 \\
(0.029)\end{array}$ & $\begin{array}{r}-.063^{* *} \\
(0.028)\end{array}$ \\
\hline Year 2015 & $\begin{array}{l}-.006 \\
(0.034)\end{array}$ & $\begin{array}{c}-.097^{* * *} \\
(0.029)\end{array}$ \\
\hline Year 2016 & $\begin{array}{c}0.078^{* *} \\
(0.039)\end{array}$ & $\begin{array}{l}-.058^{*} \\
(0.034)\end{array}$ \\
\hline Year 2017 & $\begin{array}{c}0.099^{* *} \\
(0.041)\end{array}$ & $\begin{array}{l}-.038 \\
(0.033)\end{array}$ \\
\hline Const. & $\begin{array}{c}0.549^{* *} \\
(0.231)\end{array}$ & $\begin{array}{c}0.644^{* * *} \\
(0.196)\end{array}$ \\
\hline Obs. & 1487 & 1487 \\
\hline
\end{tabular}

Source: Survey on micro and small enterprises in Uganda, waves 2013-2017, own calculations.

Notes: The table shows which socio-economic characteristics of the business owner and characteristics of the firm determine each constraint. Higher educated (a-level and university degree) and working in the services sector are the reference groups for education and industry, respectively. Standard errors in parentheses. Standard errors clustered at firm level. ${ }^{*} p<0.1,{ }^{* *} p<0.05,{ }^{* * *} p<0.01$. 
Table 7: Heterogeneity by Gender

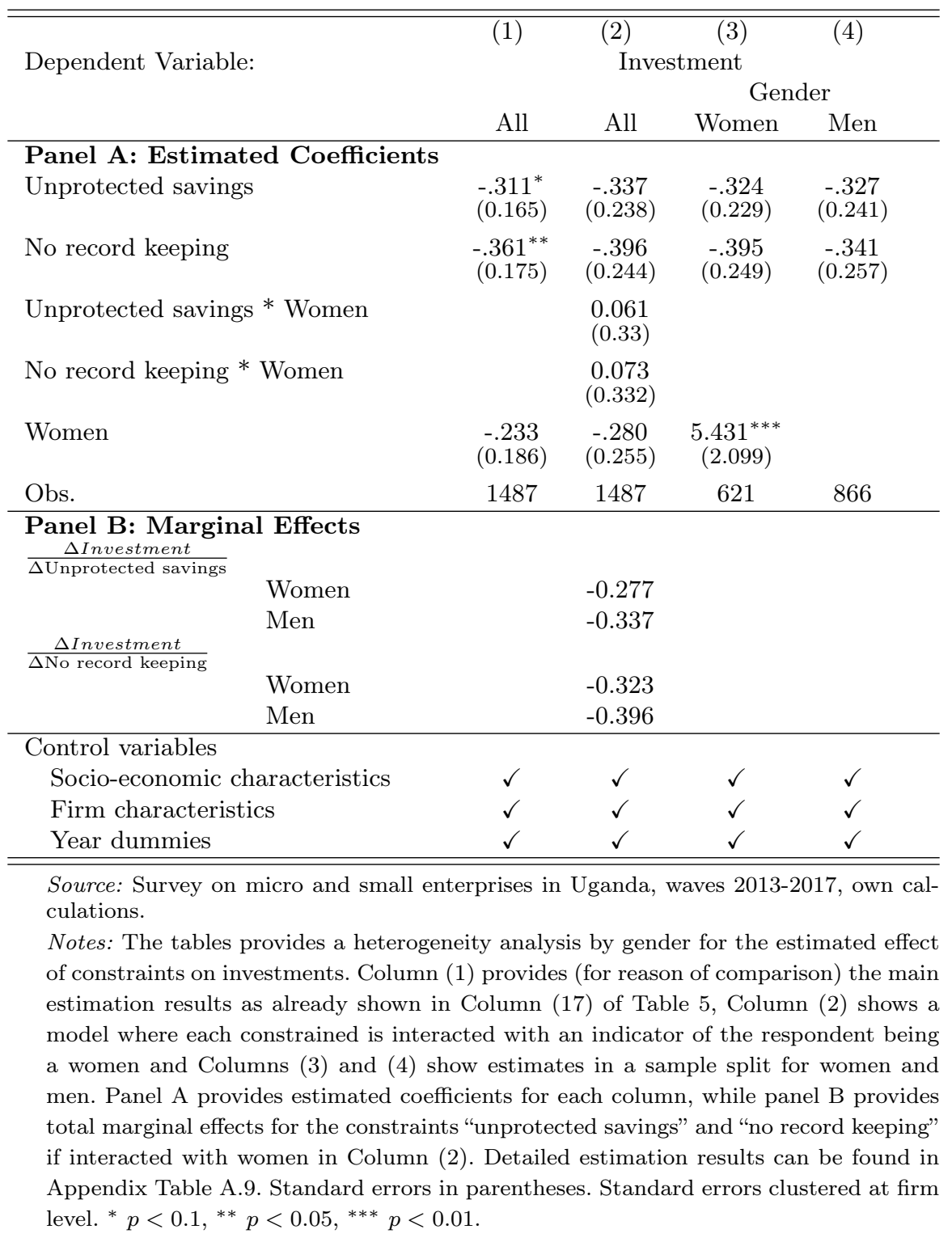


Table 8: Heterogeneity by Educational level

\begin{tabular}{|c|c|c|c|c|c|c|}
\hline \multirow{4}{*}{\multicolumn{2}{|c|}{ Dependent Variable: }} & $\overline{(1)}$ & $\overline{(2)}$ & 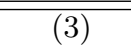 & 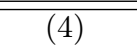 & $\overline{(5)}$ \\
\hline & & \multirow{2}{*}{\multicolumn{5}{|c|}{$\begin{array}{l}\text { Investment } \\
\text { Educational level }\end{array}$}} \\
\hline & & & & & & \\
\hline & & All & All & \multirow[t]{2}{*}{ Lower } & Medium & Highes \\
\hline \multicolumn{6}{|c|}{ Panel A: Estimated Coefficients } & \\
\hline \multicolumn{2}{|c|}{ Unprotected savings } & $\begin{array}{l}-.311^{*} \\
(0.165)\end{array}$ & $\begin{array}{c}0.117 \\
(0.356)\end{array}$ & $\begin{array}{l}-.351 \\
(0.22)\end{array}$ & $\begin{array}{l}-.567^{*} \\
(0.321)\end{array}$ & $\begin{array}{c}0.235 \\
(0.361)\end{array}$ \\
\hline \multicolumn{2}{|l|}{ No record keeping } & $\begin{array}{r}-.361^{* *} \\
(0.175)\end{array}$ & $\begin{array}{c}0.338 \\
(0.413)\end{array}$ & $\begin{array}{r}-.563^{* *} \\
(0.229)\end{array}$ & $\begin{array}{r}-.682^{* *} \\
(0.302)\end{array}$ & $\begin{array}{c}0.345 \\
(0.438)\end{array}$ \\
\hline \multicolumn{2}{|c|}{ Unprotected savings $*$ Lower educated } & & $\begin{array}{l}-.482 \\
(0.418)\end{array}$ & & & \\
\hline \multicolumn{2}{|c|}{ Unprotected savings * Medium educated } & & $\begin{array}{l}-.761 \\
(0.469)\end{array}$ & & & \\
\hline \multicolumn{2}{|c|}{ No record keeping * Lower educated } & & $\begin{array}{l}-.823^{*} \\
(0.465)\end{array}$ & & & \\
\hline \multicolumn{2}{|c|}{ No record keeping * Medium educated } & & $\begin{array}{c}-1.099^{* *} \\
(0.508)\end{array}$ & & & \\
\hline \multicolumn{2}{|l|}{ Lower educated } & $\begin{array}{l}-.022 \\
(0.249)\end{array}$ & $\begin{array}{c}0.242 \\
(0.292)\end{array}$ & & & \\
\hline \multicolumn{2}{|l|}{ Medium educated } & $\begin{array}{l}-.115 \\
(0.24)\end{array}$ & $\begin{array}{l}0.315 \\
(0.303)\end{array}$ & & & \\
\hline \multicolumn{2}{|l|}{ Obs. } & 1487 & 1487 & 623 & 389 & 475 \\
\hline \multicolumn{7}{|c|}{$\begin{array}{l}\text { Panel B: Marginal Effects } \\
\Delta \text { Investment }\end{array}$} \\
\hline & Lower educated & & $-0.365^{*}$ & & & \\
\hline & Medium educated & & $-0.644^{* *}$ & & & \\
\hline 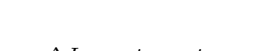 & Higher educated & & 0.117 & & & \\
\hline \multicolumn{7}{|l|}{$\frac{\Delta \text { Investment }}{\Delta \text { No record keeping }}$} \\
\hline & Lower educated & & $-0.485^{* *}$ & & & \\
\hline & Medium educated & & $-0.761^{* *}$ & & & \\
\hline & Higher educated & & 0.338 & & & \\
\hline \multicolumn{7}{|l|}{ Control variables } \\
\hline \multirow{3}{*}{\multicolumn{2}{|c|}{$\begin{array}{l}\text { Socio-economic characteristics } \\
\text { Firm characteristics } \\
\text { Year dummies }\end{array}$}} & $\checkmark$ & $\checkmark$ & $\checkmark$ & $\checkmark$ & $\checkmark$ \\
\hline & & $\checkmark$ & $\checkmark$ & $\checkmark$ & $\checkmark$ & $\checkmark$ \\
\hline & & $\checkmark$ & $\checkmark$ & $\checkmark$ & $\checkmark$ & $\checkmark$ \\
\hline
\end{tabular}

Source: Survey on micro and small enterprises in Uganda, waves 2013-2017, own calculations.

Notes: The tables provides a heterogeneity analysis by educational level for the estimated effect of constraints on investments. Column (1) provides (for reason of comparison) the main estimation results as already shown in Column (17) of Table 5 . Column (2) shows a model where each constrained is interacted with an indicator for lower and medium educated and Columns (3), (4) and (5) show estimates in a sample split for lower, medium and higher educated. Panel A provides estimated coefficients for each column, while panel B provides total marginal effects for the constraints "unprotected savings" and "no record keeping" if interacted with educational categories for Column (2). Detailed estimation results can be found in Appendix Table A.10 Standard errors in parentheses. Standard errors clustered at firm level. ${ }^{*} p<0.1,{ }^{* *} p<0.05,{ }^{* * *} p<0.01$ 


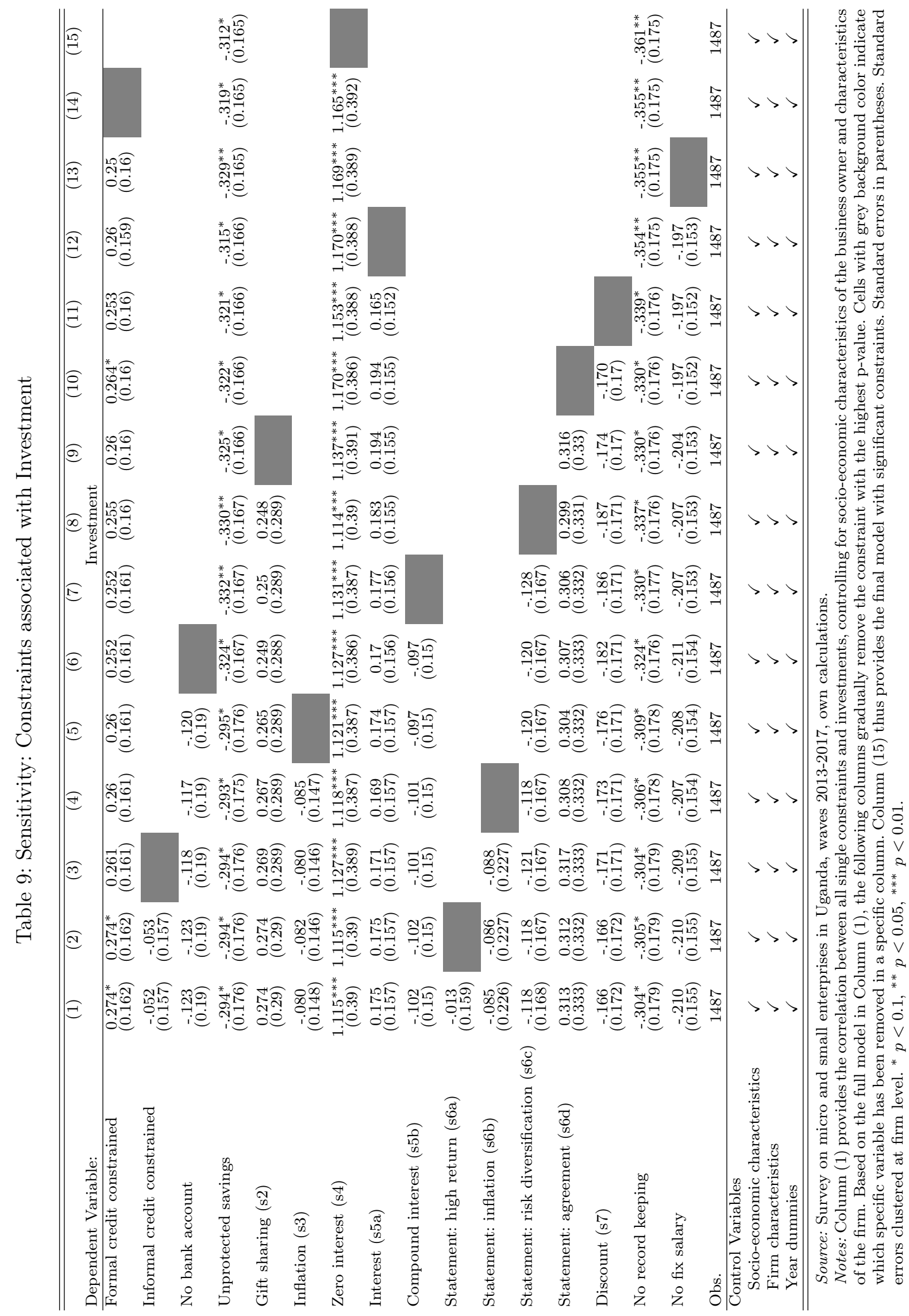


Table 10: Sensitivity Analysis: Constraints associated with Investment

\begin{tabular}{|c|c|c|c|c|}
\hline Dependent Variable: & $\begin{array}{c}(1) \\
\text { POLS } \\
\text { Investment }\end{array}$ & $\begin{array}{c}(2) \\
\text { Past RCT's } \\
\text { Investment }\end{array}$ & $\begin{array}{c}(3) \\
\text { Investment }>0 \\
\text { Investment }\end{array}$ & $\begin{array}{c}(4) \\
\text { Dummy } \\
\text { Investment }\end{array}$ \\
\hline Unprotected savings & $\begin{array}{l}-.331^{* *} \\
(0.165)\end{array}$ & $\begin{array}{l}-.359^{* *} \\
(0.172)\end{array}$ & $\begin{array}{l}-.236 \\
(0.147)\end{array}$ & $\begin{array}{l}-.029 \\
(0.028)\end{array}$ \\
\hline No record keeping & $\begin{array}{r}-.403^{* *} \\
(0.174)\end{array}$ & $\begin{array}{r}-.431^{* *} \\
(0.179)\end{array}$ & $\begin{array}{c}-.370^{* *} \\
(0.159)\end{array}$ & $\begin{array}{l}-.024 \\
(0.032)\end{array}$ \\
\hline Women & $\begin{array}{l}-.201 \\
(0.183)\end{array}$ & $\begin{array}{l}-.248 \\
(0.189)\end{array}$ & $\begin{array}{l}-.216 \\
(0.188)\end{array}$ & $\begin{array}{l}-.028 \\
(0.035)\end{array}$ \\
\hline Married & $\begin{array}{l}0.084 \\
(0.156)\end{array}$ & $\begin{array}{l}0.041 \\
(0.16)\end{array}$ & $\begin{array}{l}-.074 \\
(0.142)\end{array}$ & $\begin{array}{l}0.027 \\
(0.027)\end{array}$ \\
\hline Age & $\begin{array}{l}-.055 \\
(0.065)\end{array}$ & $(-.054)$ & $\begin{array}{c}0.023 \\
(0.076)\end{array}$ & $\begin{array}{l}-.013 \\
(0.011)\end{array}$ \\
\hline Age squared & $\begin{array}{c}0.0003 \\
(0.0008)\end{array}$ & $\begin{array}{c}0.0002 \\
(0.0008)\end{array}$ & $\begin{array}{l}-.0004 \\
(0.001)\end{array}$ & $\begin{array}{l}0.00009 \\
(0.0001)\end{array}$ \\
\hline Lower educated & $\begin{array}{l}-.022 \\
(0.245)\end{array}$ & $\begin{array}{c}0.02 \\
(0.255)\end{array}$ & $\begin{array}{l}-.356 \\
(0.248)\end{array}$ & $\begin{array}{c}0.051 \\
(0.042)\end{array}$ \\
\hline Medium educated & $\begin{array}{l}-.096 \\
(0.237)\end{array}$ & $\begin{array}{l}-.068 \\
(0.247)\end{array}$ & $\begin{array}{l}-.252 \\
(0.234)\end{array}$ & $\begin{array}{l}0.015 \\
(0.04)\end{array}$ \\
\hline Cognitive ability (raven score) & $\begin{array}{c}0.023 \\
(0.033)\end{array}$ & $\begin{array}{c}0.03 \\
(0.035)\end{array}$ & $\begin{array}{l}0.018 \\
(0.034)\end{array}$ & $\begin{array}{c}0.004 \\
(0.006)\end{array}$ \\
\hline Business experience & $\begin{array}{c}0.009 \\
(0.052)\end{array}$ & $\begin{array}{c}0.013 \\
(0.046)\end{array}$ & $\begin{array}{l}-.041 \\
(0.038)\end{array}$ & $\begin{array}{c}0.007 \\
(0.007)\end{array}$ \\
\hline Planned investment & $\begin{array}{l}0.51^{* *} \\
(0.201)\end{array}$ & $\begin{array}{l}0.514^{* *} \\
(0.206)\end{array}$ & $\begin{array}{l}0.248 \\
(0.183)\end{array}$ & $\begin{array}{c}0.079^{* *} \\
(0.037)\end{array}$ \\
\hline Age of firm & $\begin{array}{l}-.002 \\
(0.062)\end{array}$ & $\begin{array}{l}-.020 \\
(0.061)\end{array}$ & $\begin{array}{l}0.002 \\
(0.054)\end{array}$ & $\begin{array}{l}-.003 \\
(0.009)\end{array}$ \\
\hline Age of firm squared & $\begin{array}{l}-.0003 \\
(0.001)\end{array}$ & $\begin{array}{l}0.0003 \\
(0.001)\end{array}$ & $\begin{array}{l}0.001 \\
(0.001)\end{array}$ & $\begin{array}{l}-.0002 \\
(0.0002)\end{array}$ \\
\hline Initial capital stock (USD) & $\begin{array}{c}1.55 \mathrm{e}-06^{* * *} \\
(5.96 \mathrm{e}-07)\end{array}$ & $\begin{array}{c}1.29 \mathrm{e}-06^{* * *} \\
(4.85 \mathrm{e}-07)\end{array}$ & $\begin{array}{c}-4.98 \mathrm{e}-07 \\
(3.72 \mathrm{e}-07)\end{array}$ & $\begin{array}{c}3.67 \mathrm{e}-07^{* * *} \\
(7.61 \mathrm{e}-08)\end{array}$ \\
\hline Own-account worker & $\begin{array}{c}-.491^{* * *} \\
(0.155)\end{array}$ & $\begin{array}{c}-.510^{* * *} \\
(0.16)\end{array}$ & $\begin{array}{c}-.666^{* * *} \\
(0.149)\end{array}$ & $\begin{array}{l}-.003 \\
(0.028)\end{array}$ \\
\hline Registered with revenue authority & $\begin{array}{c}0.464^{* *} \\
(0.217)\end{array}$ & $\begin{array}{l}0.357 \\
(0.221)\end{array}$ & $\begin{array}{l}0.285 \\
(0.18)\end{array}$ & $\begin{array}{c}0.031 \\
(0.034)\end{array}$ \\
\hline Manufacturing (printing, paper) & $\begin{array}{l}-.109 \\
(0.353)\end{array}$ & $\begin{array}{l}-.189 \\
(0.362)\end{array}$ & $\begin{array}{c}0.879^{* * *} \\
(0.323)\end{array}$ & $\begin{array}{c}-.112^{* *} \\
(0.056)\end{array}$ \\
\hline Manufacturing (textile) & $\begin{array}{c}-.777^{* * *} \\
(0.251)\end{array}$ & $\begin{array}{c}-.687^{* *} \\
(0.268)\end{array}$ & $\begin{array}{c}-1.017^{* * *} \\
(0.259)\end{array}$ & $\begin{array}{c}0.008 \\
(0.048)\end{array}$ \\
\hline Manufacturing (remaining) & $\begin{array}{l}-.327 \\
(0.296)\end{array}$ & $\begin{array}{l}-.290 \\
(0.306)\end{array}$ & $\begin{array}{l}-.136 \\
(0.267)\end{array}$ & $\begin{array}{l}-.049 \\
(0.049)\end{array}$ \\
\hline Retail and Wholesale (remaining) & $\begin{array}{c}-1.446^{* * *} \\
(0.26)\end{array}$ & $\begin{array}{c}-1.419^{* * *} \\
(0.277)\end{array}$ & $\begin{array}{r}-.617^{* *} \\
(0.312)\end{array}$ & $\begin{array}{c}-.224^{* * *} \\
(0.05)\end{array}$ \\
\hline Retail and Wholesale (retail, clothing) & $\begin{array}{c}-.985^{* * *} \\
(0.324)\end{array}$ & $\begin{array}{c}-.972^{* * *} \\
(0.328)\end{array}$ & $\begin{array}{l}-.269 \\
(0.304)\end{array}$ & $\begin{array}{l}-.140^{* *} \\
(0.062)\end{array}$ \\
\hline Retail and Wholesale (electric, phones) & $(0.381)$ & $\begin{array}{l}-.572 \\
(0.405)\end{array}$ & $\begin{array}{l}0.017 \\
(0.325)\end{array}$ & $\begin{array}{r}-.128^{* *} \\
(0.065)\end{array}$ \\
\hline Remaining sectors & $\begin{array}{c}-1.193^{* *} \\
(0.495)\end{array}$ & $\begin{array}{c}-1.045^{* *} \\
(0.531)\end{array}$ & $\begin{array}{l}0.184 \\
(0.461)\end{array}$ & $\begin{array}{c}-.233^{* * *} \\
(0.087)\end{array}$ \\
\hline Treatment April 2016 & & $\begin{array}{l}0.449^{*} \\
(0.255)\end{array}$ & & \\
\hline Treatment April 2013 & & $\begin{array}{l}-.429^{* *} \\
(0.178)\end{array}$ & & \\
\hline Const. & $\begin{array}{c}4.514^{* * *} \\
(1.265)\end{array}$ & $\begin{array}{c}4.746^{* * *} \\
(1.276)\end{array}$ & $\begin{array}{c}5.434^{* * *} \\
(1.366)\end{array}$ & $\begin{array}{c}0.784^{* * *} \\
(0.213)\end{array}$ \\
\hline Obs. & 1487 & 1425 & 918 & 1487 \\
\hline
\end{tabular}

Source: Survey on micro and small enterprises in Uganda, waves 2013-2017, own calculations.

Notes: Higher educated (a-level and university degree) and working in the services sector are the reference groups for education and industry, respectively. Sensitivity tests are presented in the different columns, the following specifications are tested:

Column (1): Pooled ordinary least-squares (POLS) estimation.

Column (2): Estimation controls for past RCTs conducted in April 2013 and April 2016.

Column (3): Estimation is restricted to strictly positive investments in a given wave.

Column (4): Dependent variable is dichotomous indicating whether someone made an investment in a specific wave or not. Standard errors in parentheses. Standard errors clustered at firm level. ${ }^{*} p<0.1$, ${ }^{* *} p<0.05,{ }^{* * *} p<0.01$. 


\section{A Appendix A}

Table A.1: Panel Attrition 2013-2017

\begin{tabular}{lcccccc}
\hline \hline & $(1)$ & $(2)$ & $(3)$ & $(4)$ & $(5)$ & $(6)$ \\
& 2013 & 2014 & 2015 & 2016 & 2017 & \#firms \\
\hline & & & & & & 206 \\
& & & & & & 32 \\
& & & & & & 47 \\
& & & & & & 47 \\
\#firms & 380 & 347 & 292 & 252 & 216 & \\
attrition rate & & 0.09 & 0.23 & 0.34 & 0.43 & \\
\hline \hline
\end{tabular}

Source: Survey on micro and small enterprises in Uganda, waves 2013-2017, own calculations. Numbers refer to the estimation sample.

Notes: The table provides an overview on how long firms stay in the sample, the number of firms in each year and on panel attrition The shaded areas refer to the waves in which a firm is observed in the sample. Based on all firms in the estimation sample in 2013, 206 firms stay 5 consecutive waves in the panel (Row 1), 32 for 4 waves (Row 2), 47 for 3 waves (Row 3), 52 for 2 waves (Row 4) and 47 for 1 wave only (Row 5). The row labelled with '\#firms' gives the number of firms which are observed in the respective waves e.g. in 2013 there are 383 firms in the estimation sample. The last row gives the attrition rate. For example in 2014, 9 percent of firms observed in 2013 are not in the survey any more.

Table A.2: Reasons for being Credit (Un)constrained

\begin{tabular}{lll}
\hline \hline & $\begin{array}{c}(1) \\
\text { Formal } \\
\text { share }\end{array}$ & $\begin{array}{c}(2) \\
\text { Informal } \\
\text { share }\end{array}$ \\
\hline A. Credit Constrained & & \\
Expected rejection & 20.56 & 8.82 \\
Unfamiliar with process & 9.81 & 2.06 \\
Does not know source & 0.93 & 7.69 \\
Uncomfortable & 54.44 & 68.86 \\
Not registered & 2.10 & 0.56 \\
Unable to pay back & 2.80 & 2.81 \\
Rejected & 0.93 & 1.50 \\
Not full amount & 4.44 & 4.50 \\
Religious reasons & 3.97 & 3.19 \\
\hline Sum & $\mathbf{1 0 0}$ & $\mathbf{1 0 0}$ \\
B. Credit Unconstrained & & \\
Interest rates too high & 30.33 & 16.27 \\
Received full amount & 34.21 & 27.11 \\
No need & 35.46 & 56.62 \\
\hline Sum & $\mathbf{1 0 0}$ & $\mathbf{1 0 0}$ \\
\hline \hline
\end{tabular}

Source: Survey on micro and small enterprises in Uganda, waves 2013-2017, own calculations. Summary statistics refer to the estimation sample.

Notes: The table provides an overview on the reasons of being credit constrained (Panel A) or unconstrained (Panel B). In each case the shares are provided for those being formal credit (un)constrained (Column (1)) and those being informal credit (un)constrained (Column $(2))$ 
Table A.3: Financial Literacy Items

\begin{tabular}{|c|c|c|}
\hline $\begin{array}{l}\text { (1) } \\
\text { Item Abbreviation }\end{array}$ & $\begin{array}{c}(2) \\
\text { Item }\end{array}$ & $\begin{array}{l}\text { (3) } \\
\text { Survey Question }\end{array}$ \\
\hline Gift sharing & s2 & $\begin{array}{l}\text { Imagine that five brothers are given a gift of } 10,000,000 \text { UGX. If the brothers have } \\
\text { to share the money equally how much does each one get? }\end{array}$ \\
\hline Inflation & s3 & $\begin{array}{l}\text { Imagine that you get a gift of } 300,000 \text { UGX, and you put it at home for } 12 \text { months. } \\
\text { Inflation stays at } 10 \% \text {. After one year, how much could you buy for this money? }\end{array}$ \\
\hline Zero interest & s4 & $\begin{array}{l}\text { You lend } 100,000 \text { UGX to a friend one evening and he gives you 100,000 UGX } \\
\text { back the next month. How much interest has he paid on this loan? }\end{array}$ \\
\hline Interest & s5a & $\begin{array}{l}\text { Suppose you put } 100,000 \text { UGX into a savings account with a guaranteed interest } \\
\text { rate of } 2 \% \text { per year. You do not have to pay fees, you don't make any further } \\
\text { payments into this account and you don't withdraw any money. How much would } \\
\text { be in the account at the end of the first year, once the interest payment is made? }\end{array}$ \\
\hline \multirow{2}{*}{ Compound interest } & s5b & How much would be in the account at the end of five years? \\
\hline & s6 & I would like to ask you whether you think the following statements are true or false \\
\hline Statement: high return & s6a & An investment with high return is likely to be of high risk \\
\hline Statement: inflation & $\mathrm{s} 6 \mathrm{~b}$ & High inflation means that the cost of living is increasing sharply \\
\hline Statement: risk diversification & s6c & $\begin{array}{l}\text { It is less likely that you will lose all of your money if you save it in more than one } \\
\text { place }\end{array}$ \\
\hline Statement: agreement & s6d & $\begin{array}{l}\text { A financial institution needs to get your agreement first before sharing your } \\
\text { information with someone else }\end{array}$ \\
\hline Discount & s7 & $\begin{array}{l}\text { Imagine the same cell-phone is on sale in two different shops at } 200,000 \text { UGX and } \\
\text { one shop offered a discount of } 30,000 \text { UGX and the other shop offered a } 10 \% \\
\text { discount: which one is the better bargain? }\end{array}$ \\
\hline
\end{tabular}

Source: Survey on micro and small enterprises in Uganda.

Notes: Column (1) shows the item label, Column (2) the item number as used in the survey, Column (3) gives the exact survey question. 
Table A.4: Constraints associated with Investments (detailed Results)

\begin{tabular}{|c|c|}
\hline Dependent Variable: & $\begin{array}{l}\text { (1) } \\
\text { Investment }\end{array}$ \\
\hline Unprotected savings & $\begin{array}{l}-.311^{*} \\
(0.165)\end{array}$ \\
\hline No record keeping & $\begin{array}{l}-.361^{* *} \\
(0.175)\end{array}$ \\
\hline Women & $\begin{array}{l}-.233 \\
(0.186)\end{array}$ \\
\hline Married & $\begin{array}{l}0.047 \\
(0.161)\end{array}$ \\
\hline Age & $\begin{array}{l}-.046 \\
(0.064)\end{array}$ \\
\hline Age squared & $\begin{array}{l}0.0002 \\
(0.0008)\end{array}$ \\
\hline Lower educated & $\begin{array}{l}-.022 \\
(0.249)\end{array}$ \\
\hline Medium educated & $\begin{array}{l}-.115 \\
(0.24)\end{array}$ \\
\hline Cognitive ability (raven score) & $\begin{array}{l}0.029 \\
(0.033)\end{array}$ \\
\hline Business experience & $\begin{array}{l}0.011 \\
(0.051)\end{array}$ \\
\hline Planned investment & $\begin{array}{l}0.527^{* * *} \\
(0.204)\end{array}$ \\
\hline Age of firm & $\begin{array}{l}-.013 \\
(0.063)\end{array}$ \\
\hline Age of firm squared & $\begin{array}{l}0.00003 \\
(0.001)\end{array}$ \\
\hline Initial capital stock (USD) & $\begin{array}{l}1.44 \mathrm{e}-06^{* * *} \\
(5.27 \mathrm{e}-07)\end{array}$ \\
\hline Own-account worker & $\begin{array}{l}-.435^{* * *} \\
(0.155)\end{array}$ \\
\hline Registered with revenue authority & $\begin{array}{l}0.39^{*} \\
(0.219)\end{array}$ \\
\hline Manufacturing (printing, paper) & $\begin{array}{l}-.067 \\
(0.356)\end{array}$ \\
\hline Manufacturing (textile) & $\begin{array}{l}-.781^{* * *} \\
(0.255)\end{array}$ \\
\hline Manufacturing (remaining) & $\begin{array}{l}-.280 \\
(0.299)\end{array}$ \\
\hline Retail and Wholesale (remaining) & $\begin{array}{l}-1.402^{* * *} \\
(0.268)\end{array}$ \\
\hline Retail and Wholesale (retail, clothing) & $\begin{array}{l}-.969^{* * *} \\
(0.328)\end{array}$ \\
\hline Retail and Wholesale (electric, phones) & $\begin{array}{l}-.636 \\
(0.39)\end{array}$ \\
\hline Remaining sectors & $\begin{array}{l}-1.192^{* *} \\
(0.514)\end{array}$ \\
\hline Year 2014 & $\begin{array}{l}0.747^{* * *} \\
(0.185)\end{array}$ \\
\hline Year 2015 & $\begin{array}{l}0.35^{*} \\
(0.202)\end{array}$ \\
\hline Year 2016 & $\begin{array}{l}0.448^{* *} \\
(0.219)\end{array}$ \\
\hline Year 2017 & $\begin{array}{l}1.392^{* * *} \\
(0.232)\end{array}$ \\
\hline Obs. & 1487 \\
\hline
\end{tabular}

Source: Survey on micro and small enterprises in Uganda, waves 2013-2017, own calculations.

Notes: The table shows the main estimation from Column (17) in Table 5 and additionally provides the estimated coefficients of all control variables. Higher educated (a-level and university degree) and services sector are the reference groups for education and industry, respectively. Standard errors in parentheses. Standard errors clustered at firm level. ${ }^{*} p<0.1,{ }^{* *} p<0.05,{ }^{* * *} p<0.01$. 
Table A.5: Determinants of Constraints

\begin{tabular}{|c|c|c|c|c|c|c|}
\hline \multirow[b]{3}{*}{ Dependent Variable: } & \multirow{2}{*}{\multicolumn{2}{|c|}{$\begin{array}{cc}(1) & (2) \\
\text { Random Effects Model }\end{array}$}} & \multirow{2}{*}{\multicolumn{2}{|c|}{$\begin{array}{cc}(3) & (4) \\
\text { Random Effects Logit Model }\end{array}$}} & \multirow{2}{*}{\multicolumn{2}{|c|}{$\begin{array}{cc}(5) & (6) \\
\text { Random Effects Probit Model }\end{array}$}} \\
\hline & & & & & & \\
\hline & $\begin{array}{l}\text { Unprotected } \\
\text { savings }\end{array}$ & $\begin{array}{l}\text { No record } \\
\text { keeping }\end{array}$ & $\begin{array}{l}\text { Unprotected } \\
\text { savings }\end{array}$ & $\begin{array}{l}\text { No record } \\
\text { keeping }\end{array}$ & $\begin{array}{l}\text { Unprotected } \\
\text { savings }\end{array}$ & $\begin{array}{l}\text { No record } \\
\text { keeping }\end{array}$ \\
\hline Women & $\begin{array}{l}0.066^{*} \\
(0.037)\end{array}$ & $\begin{array}{l}-.049 \\
(0.037)\end{array}$ & $\begin{array}{c}0.4^{*} \\
(0.208)\end{array}$ & $\begin{array}{l}-.347 \\
(0.274)\end{array}$ & $\begin{array}{l}0.242^{* *} \\
(0.123)\end{array}$ & $\begin{array}{l}-.199 \\
(0.158)\end{array}$ \\
\hline Married & $\begin{array}{l}-.023 \\
(0.03)\end{array}$ & $\begin{array}{l}0.015 \\
(0.022)\end{array}$ & $\begin{array}{l}-.115 \\
(0.167)\end{array}$ & $\begin{array}{l}0.141 \\
(0.176)\end{array}$ & $\begin{array}{l}-.065 \\
(0.099)\end{array}$ & $\begin{array}{l}0.082 \\
(0.101)\end{array}$ \\
\hline Age & $\begin{array}{l}-.008 \\
(0.012)\end{array}$ & $\begin{array}{l}-.007 \\
(0.01)\end{array}$ & $\begin{array}{l}-.046 \\
(0.067)\end{array}$ & $\begin{array}{l}-.055 \\
(0.076)\end{array}$ & $\begin{array}{l}-.026 \\
(0.04)\end{array}$ & $\begin{array}{l}-.034 \\
(0.044)\end{array}$ \\
\hline Age squared & $\begin{array}{c}0.0001 \\
(0.0002)\end{array}$ & $\begin{array}{l}0.00007 \\
(0.0001)\end{array}$ & $\begin{array}{c}0.0006 \\
(0.0008)\end{array}$ & $\begin{array}{l}0.0005 \\
(0.0009)\end{array}$ & $\begin{array}{c}0.0003 \\
(0.0005)\end{array}$ & $\begin{array}{l}0.0003 \\
(0.0005)\end{array}$ \\
\hline Lower educated & $\begin{array}{c}0.159^{* * *} \\
(0.042)\end{array}$ & $\begin{array}{c}0.186^{* * *} \\
(0.04)\end{array}$ & $\begin{array}{c}0.895^{* * *} \\
(0.238)\end{array}$ & $\begin{array}{c}1.421^{* * *} \\
(0.334)\end{array}$ & $\begin{array}{c}0.529^{* * *} \\
(0.141)\end{array}$ & $\begin{array}{c}0.808^{* * *} \\
(0.189)\end{array}$ \\
\hline Medium educated & $\begin{array}{c}0.124^{* * *} \\
(0.039)\end{array}$ & $\begin{array}{l}0.086^{* *} \\
(0.041)\end{array}$ & $\begin{array}{c}0.706^{* * *} \\
(0.229)\end{array}$ & $\begin{array}{l}0.667^{*} \\
(0.354)\end{array}$ & $\begin{array}{c}0.411^{* * *} \\
(0.135)\end{array}$ & $\begin{array}{c}0.354^{*} \\
(0.2)\end{array}$ \\
\hline Cognitive ability (raven score) & $\begin{array}{l}-.012^{*} \\
(0.007)\end{array}$ & $\begin{array}{c}-.018^{* * *} \\
(0.006)\end{array}$ & $\begin{array}{l}-.068^{*} \\
(0.037)\end{array}$ & $\begin{array}{c}-.132^{* * *} \\
(0.046)\end{array}$ & $\begin{array}{l}-.040^{*} \\
(0.022)\end{array}$ & $\begin{array}{c}-.077^{* * *} \\
(0.027)\end{array}$ \\
\hline Business experience & $\begin{array}{l}-.013^{* *} \\
(0.005)\end{array}$ & $\begin{array}{l}-.012^{*} \\
(0.007)\end{array}$ & $\begin{array}{c}-.072^{* * *} \\
(0.028)\end{array}$ & $\begin{array}{l}-.073 \\
(0.049)\end{array}$ & $\begin{array}{c}-.042^{* * *} \\
(0.016)\end{array}$ & $\begin{array}{l}-.042 \\
(0.029)\end{array}$ \\
\hline Planned investment & $\begin{array}{l}-.031 \\
(0.033)\end{array}$ & $\begin{array}{l}-.041 \\
(0.026)\end{array}$ & $(-.174)$ & $\begin{array}{l}-.333^{*} \\
(0.195)\end{array}$ & $\begin{array}{l}-.103 \\
(0.109)\end{array}$ & $\begin{array}{l}-.183 \\
(0.113)\end{array}$ \\
\hline Age of firm & $\begin{array}{c}0.007 \\
(0.008)\end{array}$ & $\begin{array}{c}0.01 \\
(0.009)\end{array}$ & $\begin{array}{c}0.039 \\
(0.045)\end{array}$ & $\begin{array}{c}0.068 \\
(0.067)\end{array}$ & $\begin{array}{c}0.023 \\
(0.026)\end{array}$ & $\begin{array}{c}0.041 \\
(0.039)\end{array}$ \\
\hline Age of firm squared & $\begin{array}{l}0.00006 \\
(0.0002)\end{array}$ & $\begin{array}{l}1.00 \mathrm{e}-05 \\
(0.0002)\end{array}$ & $\begin{array}{l}0.0003 \\
(0.001)\end{array}$ & $\begin{array}{l}0.0001 \\
(0.002)\end{array}$ & $\begin{array}{c}0.0002 \\
(0.0008)\end{array}$ & $\begin{array}{c}0.00005 \\
(0.001)\end{array}$ \\
\hline Initial capital stock (USD) & $\begin{array}{c}3.62 \mathrm{e}-07^{* * *} \\
(1.09 \mathrm{e}-07)\end{array}$ & $\begin{array}{r}-1.05 \mathrm{e}-07^{*} \\
(5.35 \mathrm{e}-08)\end{array}$ & $\begin{array}{l}2.09 \mathrm{e}-06^{* *} \\
(8.50 \mathrm{e}-07)\end{array}$ & $\begin{array}{l}-4.94 \mathrm{e}-06 \\
(1.00 \mathrm{e}-05)\end{array}$ & $\begin{array}{l}1.26 \mathrm{e}-06^{* *} \\
(5.15 \mathrm{e}-07)\end{array}$ & $\begin{array}{l}-2.58 \mathrm{e}-06 \\
(5.92 \mathrm{e}-06)\end{array}$ \\
\hline Own-account worker & $\begin{array}{l}0.058^{* *} \\
(0.029)\end{array}$ & $\begin{array}{c}0.119 * * * \\
(0.027)\end{array}$ & $\begin{array}{l}0.324^{* *} \\
(0.161)\end{array}$ & $\begin{array}{l}0.93^{* * *} \\
(0.203)\end{array}$ & $\begin{array}{l}0.193^{* *} \\
(0.095)\end{array}$ & $\begin{array}{l}0.54^{* * *} \\
(0.116)\end{array}$ \\
\hline Registered with revenue authority & $\begin{array}{l}-.011 \\
(0.033)\end{array}$ & $\begin{array}{c}-.116^{* * *} \\
(0.025)\end{array}$ & $\begin{array}{l}-.078 \\
(0.208)\end{array}$ & $\begin{array}{c}-1.239^{* * *} \\
(0.284)\end{array}$ & $\begin{array}{l}-.045 \\
(0.122)\end{array}$ & $\begin{array}{c}-.689^{* * *} \\
(0.155)\end{array}$ \\
\hline Manufacturing (printing, paper) & $\begin{array}{l}-.073 \\
(0.063)\end{array}$ & $(0.065)$ & $\begin{array}{l}-.381 \\
(0.361)\end{array}$ & $\begin{array}{l}-.584 \\
(0.484)\end{array}$ & $\begin{array}{l}-.217 \\
(0.213)\end{array}$ & $\begin{array}{l}-.346 \\
(0.279)\end{array}$ \\
\hline Manufacturing (textile) & $\begin{array}{l}-.032 \\
(0.065)\end{array}$ & $\begin{array}{l}-.035 \\
(0.07)\end{array}$ & $\begin{array}{l}-.154 \\
(0.342)\end{array}$ & $(-.428)$ & $\begin{array}{l}-.089 \\
(0.204)\end{array}$ & $\begin{array}{l}-.249 \\
(0.267)\end{array}$ \\
\hline Manufacturing (remaining) & $\begin{array}{l}-.052 \\
(0.059)\end{array}$ & $\begin{array}{c}-.231^{* * *} \\
(0.06)\end{array}$ & $\begin{array}{l}-.231 \\
(0.322)\end{array}$ & $\begin{array}{c}-1.718^{* * *} \\
(0.441)\end{array}$ & $\begin{array}{l}-.133 \\
(0.191)\end{array}$ & $\begin{array}{l}-1.001^{* * *} \\
(0.255)\end{array}$ \\
\hline Retail and Wholesale (remaining) & $\begin{array}{l}-.022 \\
(0.06)\end{array}$ & $\begin{array}{l}-.120^{*} \\
(0.062)\end{array}$ & $\begin{array}{l}-.137 \\
(0.324)\end{array}$ & $\begin{array}{l}-.985^{* *} \\
(0.414)\end{array}$ & $\begin{array}{l}-.079 \\
(0.193)\end{array}$ & $\begin{array}{l}-.579^{* *} \\
(0.241)\end{array}$ \\
\hline Retail and Wholesale (retail, clothing) & $\begin{array}{l}-.103 \\
(0.072)\end{array}$ & $\begin{array}{l}-.161^{* *} \\
(0.067)\end{array}$ & $\begin{array}{l}-.562 \\
(0.405)\end{array}$ & $\begin{array}{c}-1.188^{* *} \\
(0.5)\end{array}$ & $\begin{array}{l}-.334 \\
(0.241)\end{array}$ & $\begin{array}{l}-.694^{* *} \\
(0.288)\end{array}$ \\
\hline Retail and Wholesale (electric, phones) & $\begin{array}{l}-.010 \\
(0.077)\end{array}$ & $\begin{array}{l}-.138^{* *} \\
(0.068)\end{array}$ & $\begin{array}{l}0.011 \\
(0.424)\end{array}$ & $\begin{array}{l}-.914^{*} \\
(0.524)\end{array}$ & $\begin{array}{l}0.01 \\
(0.25)\end{array}$ & $\begin{array}{l}-.534^{*} \\
(0.302)\end{array}$ \\
\hline Remaining sectors & $\begin{array}{l}-.172^{* *} \\
(0.079)\end{array}$ & $\begin{array}{l}-.082 \\
(0.071)\end{array}$ & $\begin{array}{l}-1.078^{*} \\
(0.57)\end{array}$ & $\begin{array}{l}-.285 \\
(0.534)\end{array}$ & $\begin{array}{l}-.628^{*} \\
(0.328)\end{array}$ & $\begin{array}{l}-.145 \\
(0.306)\end{array}$ \\
\hline Year 2014 & $\begin{array}{c}0.011 \\
(0.029)\end{array}$ & $\begin{array}{l}-.063^{* *} \\
(0.028)\end{array}$ & $\begin{array}{c}0.063 \\
(0.166)\end{array}$ & $\begin{array}{l}-.468^{* *} \\
(0.208)\end{array}$ & $\begin{array}{c}0.035 \\
(0.099)\end{array}$ & $\begin{array}{l}-.277^{* *} \\
(0.12)\end{array}$ \\
\hline Year 2015 & $\begin{array}{l}-.006 \\
(0.034)\end{array}$ & $\begin{array}{c}-.097^{* * *} \\
(0.029)\end{array}$ & $\begin{array}{l}-.032 \\
(0.198)\end{array}$ & $\begin{array}{c}-.722^{* * * *} \\
(0.226)\end{array}$ & $\begin{array}{l}-.014 \\
(0.117)\end{array}$ & $\begin{array}{c}-.429^{* * *} \\
(0.13)\end{array}$ \\
\hline Year 2016 & $\begin{array}{l}0.078^{* *} \\
(0.039)\end{array}$ & $\begin{array}{l}-.058^{*} \\
(0.034)\end{array}$ & $\begin{array}{c}0.44^{* *} \\
(0.22)\end{array}$ & $\begin{array}{l}-.461^{*} \\
(0.264)\end{array}$ & $\begin{array}{l}0.266^{* *} \\
(0.129)\end{array}$ & $\begin{array}{l}-.266^{*} \\
(0.15)\end{array}$ \\
\hline Year 2017 & $\begin{array}{l}0.099^{* *} \\
(0.041)\end{array}$ & $\begin{array}{l}-.038 \\
(0.033)\end{array}$ & $\begin{array}{l}0.553^{* *} \\
(0.227)\end{array}$ & $\begin{array}{l}-.325 \\
(0.261)\end{array}$ & $\begin{array}{l}0.329^{* *} \\
(0.134)\end{array}$ & $\begin{array}{l}-.197 \\
(0.15)\end{array}$ \\
\hline Const. & $\begin{array}{l}0.549^{* *} \\
(0.231)\end{array}$ & $\begin{array}{c}0.644^{* * *} \\
(0.196)\end{array}$ & $\begin{array}{c}0.223 \\
(1.257)\end{array}$ & $\begin{array}{l}1.178 \\
(1.482)\end{array}$ & $\begin{array}{c}0.095 \\
(0.745)\end{array}$ & $\begin{array}{c}0.735 \\
(0.851)\end{array}$ \\
\hline Obs. & 1487 & 1487 & 1487 & 1487 & 1487 & 1487 \\
\hline
\end{tabular}

Source: Survey on micro and small enterprises in Uganda, waves 2013-2017, own calculations.

Notes: The table shows a sensitivity analysis of the model estimated on the determinants of constraints. For reason of comparison, Column (1) and (2) provide again the the random effects model presented in main Table 6. Column (3) and (4) provide a random effects logit model and the remaining two columns provide a random effects probit model. Higher educated (a-level and university degree) and working in the services sector are the reference groups for education and industry, respectively. Standard errors in parentheses. Standard errors clustered at firm level. ${ }^{*} p<0.1,{ }^{* *} p<0.05,{ }^{* * *} p<0.01$. 
Table A.6: Sensitivity Analysis: Heterogeneity by Education

\begin{tabular}{|c|c|c|c|c|c|c|c|c|c|}
\hline \multirow{4}{*}{ Dependent Variable: } & $(1)$ & $(2)$ & $(3)$ & $(4)$ & $(5)$ & $(6)$ & (7) & $(8)$ & $(9)$ \\
\hline & \multicolumn{9}{|c|}{ Investment } \\
\hline & \multicolumn{5}{|c|}{ Educational level } & \multicolumn{4}{|c|}{ Highest Educational degree } \\
\hline & All & Lower & Medium & Higher & All & Primary & O-Level & A-Level & Uni \\
\hline Unprotected savings & $\begin{array}{c}0.238 \\
(0.498)\end{array}$ & $\begin{array}{l}-.351 \\
(0.22)\end{array}$ & $\begin{array}{c}-.424 \\
(0.259)\end{array}$ & $\begin{array}{c}0.581 \\
(0.496)\end{array}$ & $\begin{array}{c}0.285 \\
(0.452)\end{array}$ & $\begin{array}{l}-.424^{*} \\
(0.228)\end{array}$ & $\begin{array}{l}-.567^{*} \\
(0.321)\end{array}$ & $\begin{array}{c}0.052 \\
(0.479)\end{array}$ & $\begin{array}{c}0.581 \\
(0.496)\end{array}$ \\
\hline No record keeping & $\begin{array}{c}0.816 \\
(0.704)\end{array}$ & $\begin{array}{c}-.563^{* *} \\
(0.229)\end{array}$ & $\begin{array}{l}-.441^{*} \\
(0.264)\end{array}$ & $\begin{array}{c}0.646 \\
(0.805)\end{array}$ & $\begin{array}{c}0.522 \\
(0.566)\end{array}$ & $\begin{array}{c}-.609^{* * *} \\
(0.236)\end{array}$ & $\begin{array}{c}-.682^{* *} \\
(0.302)\end{array}$ & $\begin{array}{c}0.041 \\
(0.541)\end{array}$ & $\begin{array}{c}0.646 \\
(0.805)\end{array}$ \\
\hline Unprotected savings $*$ Medium education & $\begin{array}{c}-.672 \\
(0.548)\end{array}$ & & & & & & & & \\
\hline Unprotected savings * Lower education & $\begin{array}{l}-.604 \\
(0.543)\end{array}$ & & & & & & & & \\
\hline No record keeping $*$ Medium educated & $\begin{array}{c}-1.326^{*} \\
(0.757)\end{array}$ & & & & & & & & \\
\hline No record keeping $*$ Lower educated & $\begin{array}{c}-1.297^{*} \\
(0.735)\end{array}$ & & & & & & & & \\
\hline Lower educated & $\begin{array}{l}0.019 \\
(0.35)\end{array}$ & & & & & & & & \\
\hline Medium educated & $\begin{array}{c}-.084 \\
(0.316)\end{array}$ & & & & & & & & \\
\hline Unprotected savings $*$ Primary education & & & & & $\begin{array}{l}-.717 \\
(0.504)\end{array}$ & & & & \\
\hline Unprotected savings $*$ O-level education & & & & & $\begin{array}{l}-.921^{*} \\
(0.546)\end{array}$ & & & & \\
\hline Unprotected savings $*$ A-level education & & & & & $\begin{array}{l}-.319 \\
(0.611)\end{array}$ & & & & \\
\hline No record keeping $*$ Primary education & & & & & $\begin{array}{c}-1.044^{*} \\
(0.599)\end{array}$ & & & & \\
\hline No record keeping * O-level education & & & & & $\begin{array}{c}-1.286^{* *} \\
(0.635)\end{array}$ & & & & \\
\hline No record keeping $*$ A-level education & & & & & $\begin{array}{c}-.594 \\
(0.782)\end{array}$ & & & & \\
\hline Primary education & & & & & $\begin{array}{c}0.279 \\
(0.338)\end{array}$ & & & & \\
\hline O-level education & & & & & $\begin{array}{c}0.255 \\
(0.351)\end{array}$ & & & & \\
\hline A-level education & & & & & $\begin{array}{l}-.190 \\
(0.347)\end{array}$ & & & & \\
\hline Obs. & 1487 & 623 & 644 & 220 & 1487 & 597 & 389 & 255 & 220 \\
\hline
\end{tabular}

Source: Survey on micro and small enterprises in Uganda, waves 2013-2017, own calculations.

Notes: The table shows a sensitivity analysis of the categorization of educational groups used in the heterogeneity analysis. The robustness check conducted in Column (1) is that the group of medium educated now comprises of the group of lower and upper secondary educated (O- and A-level educated) as opposed to lower secondary educated only as in Table 8 (higher educated are the reference group). Columns (2)-(4) show the estimated effects by the different subgroup used in Column (1). Column (5) uses interactions between each binding constraints with each educational level refrains from grouping educational levels (university degree is reference group). Columns (6)-(9) show the estimated effects by the different subgroups used in Column (5). Standard errors in parentheses. Standard errors clustered at firm level. ${ }^{*} p<0.1,{ }^{* *} p<0.05,{ }^{* * *} p<0.01$. 


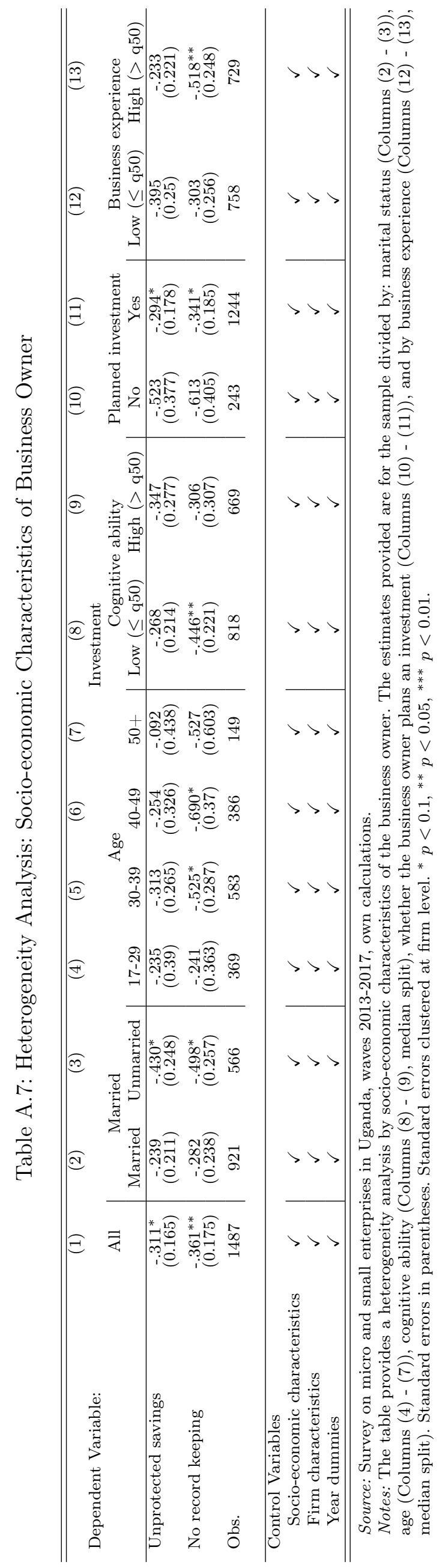




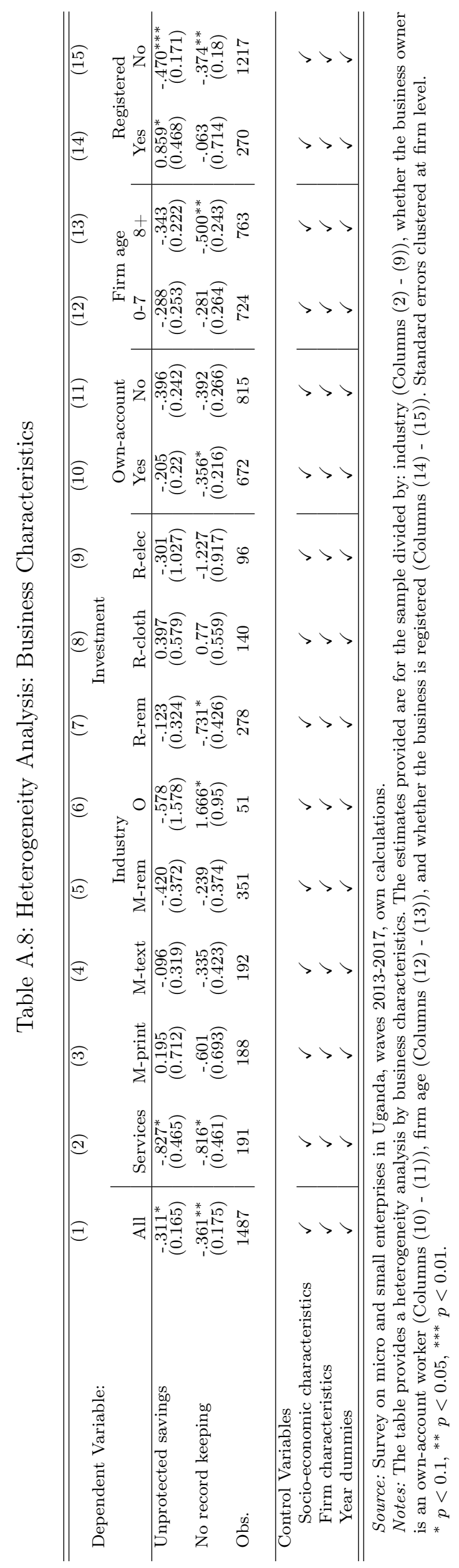


Table A.9: Heterogeneity by Gender

\begin{tabular}{|c|c|c|c|c|}
\hline \multirow{3}{*}{ Dependent Variable: } & (1) & $(2)$ & (3) & (4) \\
\hline & \multicolumn{4}{|c|}{ Investment } \\
\hline & All & All & Women & Men \\
\hline Unprotected savings & $\begin{array}{l}-.320^{*} \\
(0.165)\end{array}$ & $\begin{array}{l}-.285 \\
(0.229)\end{array}$ & $\begin{array}{l}-.324 \\
(0.229)\end{array}$ & $\begin{array}{l}-.327 \\
(0.241)\end{array}$ \\
\hline No record keeping & $\begin{array}{l}-.351^{* *} \\
(0.174)\end{array}$ & $\begin{array}{l}-.323 \\
(0.232)\end{array}$ & $\begin{array}{l}-.395 \\
(0.249)\end{array}$ & $\begin{array}{l}-.341 \\
(0.257)\end{array}$ \\
\hline Unprotected savings $*$ Women & & $\begin{array}{l}-.076 \\
(0.292)\end{array}$ & & \\
\hline No record keeping $*$ Women & & $\begin{array}{l}-.061 \\
(0.302)\end{array}$ & & \\
\hline Married & $\begin{array}{l}0.057 \\
(0.16)\end{array}$ & $\begin{array}{c}0.053 \\
(0.161)\end{array}$ & $\begin{array}{c}0.028 \\
(0.213)\end{array}$ & $\begin{array}{c}0.135 \\
(0.244)\end{array}$ \\
\hline Age & $\begin{array}{l}-.053 \\
(0.063)\end{array}$ & $\begin{array}{l}-.051 \\
(0.063)\end{array}$ & $\begin{array}{l}-.127 \\
(0.098)\end{array}$ & $\begin{array}{l}-.025 \\
(0.084)\end{array}$ \\
\hline Age squared & $\begin{array}{c}0.0002 \\
(0.0008)\end{array}$ & $\begin{array}{c}0.0002 \\
(0.0008)\end{array}$ & $\begin{array}{c}0.001 \\
(0.001)\end{array}$ & $\begin{array}{l}-.0002 \\
(0.001)\end{array}$ \\
\hline Lower educated & $\begin{array}{l}-.060 \\
(0.247)\end{array}$ & $\begin{array}{l}-.056 \\
(0.247)\end{array}$ & $\begin{array}{l}0.297 \\
(0.32)\end{array}$ & $\begin{array}{l}-.338 \\
(0.356)\end{array}$ \\
\hline Medium educated & $\begin{array}{l}-.146 \\
(0.241)\end{array}$ & $\begin{array}{l}-.145 \\
(0.241)\end{array}$ & $\begin{array}{l}0.106 \\
(0.336)\end{array}$ & $\begin{array}{l}-.154 \\
(0.338)\end{array}$ \\
\hline Cognitive ability (raven score) & $\begin{array}{c}0.033 \\
(0.033)\end{array}$ & $\begin{array}{c}0.032 \\
(0.034)\end{array}$ & $\begin{array}{c}0.034 \\
(0.047)\end{array}$ & $\begin{array}{c}0.024 \\
(0.048)\end{array}$ \\
\hline Business experience & $\begin{array}{c}0.015 \\
(0.052)\end{array}$ & $\begin{array}{c}0.014 \\
(0.052)\end{array}$ & $\begin{array}{c}0.015 \\
(0.043)\end{array}$ & $\begin{array}{l}-.028 \\
(0.058)\end{array}$ \\
\hline Planned investment & $\begin{array}{c}0.519^{* *} \\
(0.203)\end{array}$ & $\begin{array}{c}0.519^{* *} \\
(0.203)\end{array}$ & $\begin{array}{l}0.199 \\
(0.31)\end{array}$ & $\begin{array}{c}0.713^{* *} \\
(0.28)\end{array}$ \\
\hline Age of firm & $\begin{array}{l}-.012 \\
(0.064)\end{array}$ & $\begin{array}{l}-.012 \\
(0.063)\end{array}$ & $\begin{array}{c}0.035 \\
(0.076)\end{array}$ & $\begin{array}{c}0.006 \\
(0.081)\end{array}$ \\
\hline Age of firm squared & $\begin{array}{c}-.00007 \\
(0.001)\end{array}$ & $\begin{array}{c}-.00005 \\
(0.001)\end{array}$ & $\begin{array}{l}-.002 \\
(0.002)\end{array}$ & $\begin{array}{l}0.0009 \\
(0.002)\end{array}$ \\
\hline Initial capital stock (USD) & $\begin{array}{c}1.47 \mathrm{e}-06^{* * *} \\
(5.33 \mathrm{e}-07)\end{array}$ & $\begin{array}{c}1.45 \mathrm{e}-06^{* * *} \\
(5.38 \mathrm{e}-07)\end{array}$ & $\begin{array}{c}-6.40 \mathrm{e}-06 \\
(0.00002)\end{array}$ & $\begin{array}{r}1.29 \mathrm{e}-06^{* *} \\
(5.48 \mathrm{e}-07)\end{array}$ \\
\hline Own-account worker & $\begin{array}{c}-.463^{* * *} \\
(0.154)\end{array}$ & $\begin{array}{c}-.459^{* * *} \\
(0.154)\end{array}$ & $\begin{array}{c}-.519^{* *} \\
(0.247)\end{array}$ & $\begin{array}{l}-.374^{*} \\
(0.211)\end{array}$ \\
\hline Registered with revenue authority & $\begin{array}{c}0.41^{*} \\
(0.219)\end{array}$ & $\begin{array}{c}0.41^{*} \\
(0.219)\end{array}$ & $\begin{array}{c}0.394 \\
(0.357)\end{array}$ & $\begin{array}{c}0.306 \\
(0.275)\end{array}$ \\
\hline Manufacturing (printing, paper) & $\begin{array}{l}-.017 \\
(0.358)\end{array}$ & $\begin{array}{l}-.026 \\
(0.359)\end{array}$ & $\begin{array}{l}-.308 \\
(0.493)\end{array}$ & $\begin{array}{l}-.021 \\
(0.529)\end{array}$ \\
\hline Manufacturing (textile) & $\begin{array}{c}-.745^{* * *} \\
(0.251)\end{array}$ & $\begin{array}{c}-.758^{* * *} \\
(0.255)\end{array}$ & $\begin{array}{l}-.610^{*} \\
(0.328)\end{array}$ & $\begin{array}{l}-.949^{* *} \\
(0.436)\end{array}$ \\
\hline Manufacturing (remaining) & $\begin{array}{l}-.168 \\
(0.279)\end{array}$ & $\begin{array}{l}-.189 \\
(0.289)\end{array}$ & $\begin{array}{c}-1.138^{*} \\
(0.588)\end{array}$ & $\begin{array}{l}-.155 \\
(0.417)\end{array}$ \\
\hline Retail and Wholesale (remaining) & $\begin{array}{c}-1.388^{* * *} \\
(0.267)\end{array}$ & $\begin{array}{c}-1.381^{* * *} \\
(0.269)\end{array}$ & $\begin{array}{c}-1.281^{* * *} \\
(0.346)\end{array}$ & $\begin{array}{c}-1.594^{* * *} \\
(0.49)\end{array}$ \\
\hline Retail and Wholesale (retail, clothing) & $\begin{array}{c}-.999^{* * *} \\
(0.325)\end{array}$ & $\begin{array}{c}-.998^{* * *} \\
(0.326)\end{array}$ & $\begin{array}{l}-.645 \\
(0.394)\end{array}$ & $\begin{array}{c}-1.677^{* * *} \\
(0.612)\end{array}$ \\
\hline Retail and Wholesale (electric, phones) & $\begin{array}{c}-.551 \\
(0.384)\end{array}$ & $\begin{array}{l}-.567 \\
(0.388)\end{array}$ & $\begin{array}{c}-1.425^{*} \\
(0.818)\end{array}$ & $\begin{array}{l}-.560 \\
(0.481)\end{array}$ \\
\hline Remaining sectors & $\begin{array}{c}-1.178^{* *} \\
(0.518)\end{array}$ & $\begin{array}{c}-1.181^{* *} \\
(0.518)\end{array}$ & $\begin{array}{c}-1.056^{* *} \\
(0.443)\end{array}$ & $\begin{array}{l}-1.198 \\
(0.897)\end{array}$ \\
\hline Year 2014 & $\begin{array}{c}0.744^{* * *} \\
(0.185)\end{array}$ & $\begin{array}{c}0.746^{* * *} \\
(0.185)\end{array}$ & $\begin{array}{c}0.771^{* * *} \\
(0.276)\end{array}$ & $\begin{array}{c}0.706^{* * *} \\
(0.261)\end{array}$ \\
\hline Year 2015 & $\begin{array}{l}0.348^{*} \\
(0.202)\end{array}$ & $\begin{array}{c}0.35^{*} \\
(0.202)\end{array}$ & $\begin{array}{l}0.524^{*} \\
(0.302)\end{array}$ & $\begin{array}{c}0.236 \\
(0.274)\end{array}$ \\
\hline Year 2016 & $\begin{array}{c}0.443^{* *} \\
(0.22)\end{array}$ & $\begin{array}{c}0.445^{* *} \\
(0.22)\end{array}$ & $\begin{array}{l}0.494 \\
(0.33)\end{array}$ & $\begin{array}{c}0.414 \\
(0.299)\end{array}$ \\
\hline Year 2017 & $\begin{array}{c}1.386^{* * *} \\
(0.232)\end{array}$ & $\begin{array}{c}1.389^{* * *} \\
(0.233)\end{array}$ & $\begin{array}{c}1.215^{* * *} \\
(0.356)\end{array}$ & $\begin{array}{c}1.465^{* * *} \\
(0.318)\end{array}$ \\
\hline Obs. & 1487 & 1487 & 621 & 866 \\
\hline
\end{tabular}

Source: Survey on micro and small enterprises in Uganda, waves 2013-2017, own calculations.

Notes: Standard errors in parentheses. Standard errors clustered at firm level. ${ }^{*} p<0.1,{ }^{* *} p<0.05$, *** $p<0.01$. 
Table A.10: Heterogeneity by Education

\begin{tabular}{|c|c|c|c|c|c|}
\hline \multirow{2}{*}{ Dependent Variable: } & $(1)$ & $(2)$ & $\begin{array}{c}(3) \\
\text { Invest }\end{array}$ & $(4)$ & $(5)$ \\
\hline & All & All & \multicolumn{2}{|l|}{ Investment } & High \\
\hline Unprotected savings & $\begin{array}{l}-.311^{*} \\
(0.165)\end{array}$ & $\begin{array}{l}0.117 \\
(0.356)\end{array}$ & $\begin{array}{l}-.351 \\
(0.22)\end{array}$ & $\begin{array}{l}-.567^{*} \\
(0.321)\end{array}$ & $\begin{array}{l}0.235 \\
(0.361)\end{array}$ \\
\hline No record keeping & $\begin{array}{c}-.361^{* *} \\
(0.175)\end{array}$ & $\begin{array}{l}0.338 \\
(0.413)\end{array}$ & $\begin{array}{l}-.563^{* *} \\
(0.229)\end{array}$ & $\begin{array}{l}-.682^{* *} \\
(0.302)\end{array}$ & $\begin{array}{c}0.345 \\
(0.438)\end{array}$ \\
\hline Unprotected savings * Lower educated & & $\begin{array}{l}-.482 \\
(0.418)\end{array}$ & & & \\
\hline Unprotected savings $*$ Medium educated & & $\begin{array}{l}-.761 \\
(0.469)\end{array}$ & & & \\
\hline No record keeping $*$ Low skilled (no, primary) & & $\begin{array}{l}-.823^{*} \\
(0.465)\end{array}$ & & & \\
\hline No record keeping $*$ Medium skilled (o-level) & & $\begin{array}{c}-1.099^{* *} \\
(0.508)\end{array}$ & & & \\
\hline Lower educated & $\begin{array}{l}-.022 \\
(0.249)\end{array}$ & $\begin{array}{c}0.242 \\
(0.292)\end{array}$ & & & \\
\hline Medium educated & $\begin{array}{l}-.115 \\
(0.24)\end{array}$ & $\begin{array}{l}0.315 \\
(0.303)\end{array}$ & & & \\
\hline Women & $\begin{array}{l}-.233 \\
(0.186)\end{array}$ & $\begin{array}{l}-.278 \\
(0.186)\end{array}$ & $\begin{array}{c}0.029 \\
(0.284)\end{array}$ & $\begin{array}{l}-.229 \\
(0.351)\end{array}$ & $\begin{array}{l}-.713^{*} \\
(0.365)\end{array}$ \\
\hline Married & $\begin{array}{l}0.047 \\
(0.161)\end{array}$ & $\begin{array}{l}0.041 \\
(0.16)\end{array}$ & $\begin{array}{l}0.383^{*} \\
(0.226)\end{array}$ & $\begin{array}{l}-.251 \\
(0.29)\end{array}$ & $\begin{array}{l}-.120 \\
(0.349)\end{array}$ \\
\hline Age & $\begin{array}{l}-.046 \\
(0.064)\end{array}$ & $\begin{array}{l}-.049 \\
(0.063)\end{array}$ & $\begin{array}{l}-.080 \\
(0.086)\end{array}$ & $\begin{array}{l}-.057 \\
(0.129)\end{array}$ & $\begin{array}{l}-.067 \\
(0.115)\end{array}$ \\
\hline Age squared & $\begin{array}{c}0.0002 \\
(0.0008)\end{array}$ & $\begin{array}{c}0.0002 \\
(0.0008)\end{array}$ & $\begin{array}{l}0.0004 \\
(0.001)\end{array}$ & $\begin{array}{l}0.0005 \\
(0.001)\end{array}$ & $\begin{array}{l}0.0004 \\
(0.001)\end{array}$ \\
\hline Cognitive ability (raven score) & $\begin{array}{c}0.029 \\
(0.033)\end{array}$ & $\begin{array}{c}0.029 \\
(0.033)\end{array}$ & $\begin{array}{l}-.001 \\
(0.045)\end{array}$ & $\begin{array}{l}0.175^{* *} \\
(0.069)\end{array}$ & $\begin{array}{l}-.024 \\
(0.063)\end{array}$ \\
\hline Business experience & $\begin{array}{c}0.011 \\
(0.051)\end{array}$ & $\begin{array}{l}0.002 \\
(0.05)\end{array}$ & $\begin{array}{c}0.081 \\
(0.073)\end{array}$ & $\begin{array}{l}0.018 \\
(0.043)\end{array}$ & $\begin{array}{l}-.133^{* *} \\
(0.064)\end{array}$ \\
\hline Planned investment & $\begin{array}{c}0.527^{* * *} \\
(0.204)\end{array}$ & $\begin{array}{c}0.506^{* *} \\
(0.203)\end{array}$ & $\begin{array}{c}0.244 \\
(0.293)\end{array}$ & $\begin{array}{l}0.609 \\
(0.45)\end{array}$ & $\begin{array}{c}0.842^{* *} \\
(0.387)\end{array}$ \\
\hline Age of firm & $\begin{array}{l}-.013 \\
(0.063)\end{array}$ & $\begin{array}{l}-.005 \\
(0.061)\end{array}$ & $\begin{array}{l}-.056 \\
(0.083)\end{array}$ & $\begin{array}{l}-.030 \\
(0.093)\end{array}$ & $\begin{array}{c}0.216 \\
(0.155)\end{array}$ \\
\hline Age of firm squared & $\begin{array}{l}0.00003 \\
(0.001)\end{array}$ & $\begin{array}{c}0.00005 \\
(0.001)\end{array}$ & $\begin{array}{l}-.0007 \\
(0.002)\end{array}$ & $\begin{array}{l}0.0001 \\
(0.003)\end{array}$ & $\begin{array}{l}-.004 \\
(0.005)\end{array}$ \\
\hline Initial capital stock (USD) & $\begin{array}{c}1.44 \mathrm{e}-06^{* * *} \\
(5.27 \mathrm{e}-07)\end{array}$ & $\begin{array}{c}1.32 \mathrm{e}-06^{* *} \\
(5.25 \mathrm{e}-07)\end{array}$ & $\begin{array}{c}7.58 \mathrm{e}-06 \\
(0.00002)\end{array}$ & $\begin{array}{c}0.00002^{* * *} \\
(4.99 \mathrm{e}-06)\end{array}$ & $\begin{array}{l}1.51 \mathrm{e}-06^{*} \\
(8.35 \mathrm{e}-07)\end{array}$ \\
\hline Own-account worker & $\begin{array}{c}-.435^{* * *} \\
(0.155)\end{array}$ & $\begin{array}{c}-.417^{* * *} \\
(0.156)\end{array}$ & $\begin{array}{l}0.012 \\
(0.241)\end{array}$ & $\begin{array}{l}-.561^{*} \\
(0.327)\end{array}$ & $\begin{array}{c}-.574^{*} \\
(0.3)\end{array}$ \\
\hline Registered with revenue authority & $\begin{array}{l}0.39^{*} \\
(0.219)\end{array}$ & $\begin{array}{l}0.409^{*} \\
(0.217)\end{array}$ & $\begin{array}{c}0.267 \\
(0.368)\end{array}$ & $\begin{array}{l}0.106 \\
(0.499)\end{array}$ & $\begin{array}{c}0.606^{*} \\
(0.32)\end{array}$ \\
\hline Manufacturing (printing, paper) & $\begin{array}{l}-.067 \\
(0.356)\end{array}$ & $\begin{array}{l}-.141 \\
(0.352)\end{array}$ & $\begin{array}{l}1.860^{*} \\
(1.058)\end{array}$ & $\begin{array}{l}-.765 \\
(0.533)\end{array}$ & $\begin{array}{l}-.712 \\
(0.564)\end{array}$ \\
\hline Manufacturing (textile) & $\begin{array}{c}-.781^{* * *} \\
(0.255)\end{array}$ & $\begin{array}{c}-.752^{* * *} \\
(0.257)\end{array}$ & $\begin{array}{l}-.516 \\
(0.39)\end{array}$ & $\begin{array}{c}-1.045^{* *} \\
(0.495)\end{array}$ & $\begin{array}{l}-.722 \\
(0.834)\end{array}$ \\
\hline Manufacturing (remaining) & $\begin{array}{l}-.280 \\
(0.299)\end{array}$ & $\begin{array}{l}-.325 \\
(0.3)\end{array}$ & $\begin{array}{c}0.283 \\
(0.447)\end{array}$ & $\begin{array}{l}-.502 \\
(0.492)\end{array}$ & $\begin{array}{l}-.833 \\
(0.647)\end{array}$ \\
\hline Retail and Wholesale (remaining) & $\begin{array}{c}-1.402^{* * *} \\
(0.268)\end{array}$ & $\begin{array}{c}-1.394^{* * *} \\
(0.266)\end{array}$ & $\begin{array}{l}-.887^{* *} \\
(0.357)\end{array}$ & $\begin{array}{c}-1.400^{* *} \\
(0.631)\end{array}$ & $\begin{array}{c}-2.815^{* * *} \\
(0.528)\end{array}$ \\
\hline Retail and Wholesale (retail, clothing) & $\begin{array}{c}-.969^{* * *} \\
(0.328)\end{array}$ & $\begin{array}{c}-.981^{* * *} \\
(0.329)\end{array}$ & $\begin{array}{l}-.190 \\
(0.565)\end{array}$ & $\begin{array}{c}-1.387^{* * *} \\
(0.52)\end{array}$ & $\begin{array}{c}-1.812^{* * *} \\
(0.639)\end{array}$ \\
\hline Retail and Wholesale (electric, phones) & $\begin{array}{l}-.636 \\
(0.39)\end{array}$ & $\begin{array}{l}-.678^{*} \\
(0.396)\end{array}$ & $\begin{array}{l}-.580 \\
(1.107)\end{array}$ & $\begin{array}{c}-1.265^{*} \\
(0.67)\end{array}$ & $\begin{array}{c}-1.045^{*} \\
(0.572)\end{array}$ \\
\hline Remaining sectors & $\begin{array}{c}-1.192^{* *} \\
(0.514)\end{array}$ & $\begin{array}{c}-1.251^{* *} \\
(0.509)\end{array}$ & & $\begin{array}{l}-1.430 \\
(1.222)\end{array}$ & $\begin{array}{c}-1.789^{* * *} \\
(0.677)\end{array}$ \\
\hline Year 2014 & $\begin{array}{c}0.747^{* * *} \\
(0.185)\end{array}$ & $\begin{array}{c}0.762^{* * *} \\
(0.185)\end{array}$ & $\begin{array}{c}1.052^{* * *} \\
(0.246)\end{array}$ & $\begin{array}{l}0.187 \\
(0.381)\end{array}$ & $\begin{array}{c}0.826^{* *} \\
(0.398)\end{array}$ \\
\hline Year 2015 & $\begin{array}{l}0.35^{*} \\
(0.202)\end{array}$ & $\begin{array}{l}0.345^{*} \\
(0.203)\end{array}$ & $\begin{array}{l}0.394 \\
(0.28)\end{array}$ & $\begin{array}{l}0.691^{*} \\
(0.406)\end{array}$ & $\begin{array}{l}-.081 \\
(0.464)\end{array}$ \\
\hline Year 2016 & $\begin{array}{l}0.448^{* *} \\
(0.219)\end{array}$ & $\begin{array}{l}0.421^{*} \\
(0.217)\end{array}$ & $\begin{array}{c}0.761^{* * *} \\
(0.283)\end{array}$ & $\begin{array}{l}0.134 \\
(0.448)\end{array}$ & $\begin{array}{l}0.132 \\
(0.48)\end{array}$ \\
\hline Year 2017 & $\begin{array}{c}1.392^{* * *} \\
(0.232)\end{array}$ & $\begin{array}{c}1.396^{* * *} \\
(0.236)\end{array}$ & $\begin{array}{c}1.639^{* * *} * \\
(0.301)\end{array}$ & $\begin{array}{c}1.320^{* * *} \\
(0.488)\end{array}$ & $\begin{array}{l}1.053^{* *} \\
(0.504)\end{array}$ \\
\hline Obs. & 1487 & 1487 & 623 & 389 & 475 \\
\hline
\end{tabular}

Source: Survey on micro and small enterprises in Uganda, waves 2013-2017, own calculations.

Notes: Standard errors in parentheses. Standard errors clustered at firm level. ${ }^{*} p<0.1,{ }^{* *} p<0.05,{ }^{* * *} p<0.01$. 